January 2003

\title{
Anticipatory Repudiation of Letters of Credit
}

Keith A. Rowley

\section{Recommended Citation}

Keith A. Rowley, Anticipatory Repudiation of Letters of Credit, 56 SMU L. REV. 2235 (2003)

https://scholar.smu.edu/smulr/vol56/iss4/5

This Article is brought to you for free and open access by the Law Journals at SMU Scholar. It has been accepted for inclusion in SMU Law Review by an authorized administrator of SMU Scholar. For more information, please visit http://digitalrepository.smu.edu. 


\title{
Anticipatory RepUdiation of LETTERS OF CREDit
}

\author{
Keith A. Rowley*
}

\begin{abstract}
$\mathrm{L}$
ETTERS of credit $^{1}$ have been facilitating commercial transactions $^{2}$ since at least the $1100 \mathrm{~s}^{3}$ and quite possibly for hundreds, if not thousands, of years more. ${ }^{4}$ Today, at any given time, hundreds
\end{abstract}

* Associate Professor of Law, William S. Boyd School of Law, University of Nevada Las Vegas. J.D., University of Texas School of Law; M.P.P., Harvard University, John F. Kennedy School of Government; B.A., Baylor University. I want to thank Joe Perillo for inspiring me to delve into the minutiae of anticipatory repudiation; John Dolan, Ronald Mann, Bruce Markell, Margaret Moses, and Tim Zinnecker for their helpful comments; Dean Richard J. Morgan and the rest of my colleagues for the release time that enabled me to write this article; Ira David and Colt Dodrill for their research assistance; and James E. Rogers for his ongoing support of faculty research at the Boyd School of Law.

1. A letter of credit is "a definite undertaking ... by an issuer to a beneficiary at the request or for the account of an applicant or, in the case of a financial institution, to itself or for its own account, to honor a documentary presentation by payment or delivery of an item of value." U.C.C. $\$$ 5-102(10) (1995); see also Republic Nat'l Bank v. Northwest Nat'l Bank, 578 S.W.2d 109, 115 (Tex. 1979) ("The engagement is a letter of credit if the issuer has a primary obligation that is dependent solely upon presentation of conforming documents and not upon the factual performance or nonperformance by the parties to the underlying transaction."); International Chamber of Commerce, Pub. No. 500, Uniform Customs and Practice for Documentary Credits art. 2 (1993) [hereinafter UCP500] (defining a letter of credit as "any arrangement, however named or described, whereby a bank (the 'Issuing Bank') acting at the request of a customer (the 'Applicant') or on its own behalf," inter alia, "is to make a payment to or to the order of a third party (the 'Beneficiary')").

2. Letters of credit facilitate commercial transactions "by providing the credit of a third party, usually a bank, as an independent guarantee of payment to protect the parties. The certainty of payment ... encourages hesitant parties to enter into transactions, by providing them with a secure source of credit." AmSouth Bank, N.A. v. Martin, 559 So. 2d 1058, 1062 (Ala. 1990) (paraphrasing Christopher Leon, Letters of Credit: A Primer, 45 MD. L. Rev. 432, 432 (1986)).

3. A number of sources date the origins of letters of credit to the 1100s. See, e.g., Republic Nat'l Bank, 578 S.W.2d at 113; Leon, supra note 2, at 433; Paul R. Verkuil, Bank Solvency and Guaranty Letters of Credit, 25 STAN. L. Rev. 716, 716 n.1 (1979); Richard A. Wiley, How to Use Letters of Credit in Financing the Sale of Goods, 20 Bus. Law. 495, 495 (1965).

4. Other sources date the origins of letters of credit much earlier. See Moog World Trade Corp. v. Bancomer, S.A., 90 F.3d 1382, 1385 (8th Cir. 1996) ("Letters of credit have been used for nearly 3000 years."); Wilbert Ware \& Henry Harfield, Bank Credits AND ACCEPTANCES 145 (4th ed. 1958) (suggesting 575 B.C. as a likely starting date for the use of letters of credit); Wiley, supra note 3 , at 495 (suggesting that letters of credit may date "as far back as the time of the Phoenicians, Babylonians, Assyrians, and Greeks"); Rufus James Trimble, The Law Merchant and the Letter of Credit, 61 HARv. L. REv. 981, 983-86 (1948) (tracing the origins of letters of credit to the ancient Egyptians, Phoenicians, and Greeks). 
of billions of dollars worth of commercials ${ }^{5}$ and standby 6 letters of credit are outstanding. ${ }^{7}$ In the words of a recent opinion by the New York Court of Appeals, "[t]he importance of letters of credit in international trade and financing cannot be overstated." 8

In a typical commercial transaction, a buyer and a seller agree that the buyer will purchase goods or services from the seller, for cash or on credit, and that the seller will provide the buyer with those goods or services in exchange for the buyer's payment or promise to pay. Each party undertakes an obligation to the other in expectation of a benefit to be conferred by the other. These obligations are mutually dependent, such that one party's failure to perform may excuse the other party from performing. ${ }^{9}$ A letter of credit transaction introduces a third party-the letter of credit "issuer" 10 - and two additional undertakings-or, as one leading commentator describes them, "relationships"11_to the transaction.

The first undertaking in a letter of credit transaction is the underlying contract between the buyer and the seller, which is now conditioned on the buyer arranging for a letter of credit on the seller's behalf. ${ }^{12}$ If the letter of credit is a commercial letter of credit, the underlying contract is for the sale of goods. ${ }^{13}$ If the letter of credit is a standby letter of credit, ${ }^{14}$ then the underlying contract may be a promissory note or similar obliga-

5. See infra notes $43-46$ and accompanying text.

6. See infra notes 47-51 and accompanying text.

7. See James E. Byrne, Overview of Letter of Credit Law \& Practice in 2000, in AN. nual Survey of LetTer of Credit Law \& Practice 3 n.1 (James E. Byrne \& Christopher S. Byrnes, eds., 2001) (estimating standby and commercial letters of credit outstanding by U.S. issuers and by non-U.S. issuers to U.S. beneficiaries in the third quarter of 2000 in excess of $\$ 700$ billion); see also LC Statistics: 2nd Quarter 2002, DOCUMENTARY CREDIT WORLD, Oct. 2002 , at $23-33$ (reporting $\$ 281.7$ billion and $\$ 146.9$ billion outstanding standby and commercial letters of credit issued by 300 leading U.S. banks and 226 leading U.S. branches or agencies of non-U.S. banks, respectively); Prefatory Note to U.C.C. Revised Article 5 (1995) (commenting that, as of 1995, "nearly $\$ 500$ billion standby letters of credit are issued annually worldwide, of which $\$ 250$ billion are issued in the United States").

8. Nissho Iwai Europe PLC v. Korea First Bank, 782 N.E.2d 55, 58 n.1 (N.Y. 2002).

9. See, e.g., U.C.C. $\$ 2-703$ (a), (f) (1989) (empowering the seller, inter alia, to withhold delivery of goods or to cancel the contract if the buyer fails to perform as promised); id. $\$ 2-711(1)$ (empowering the buyer, inter alia, to cancel the contract if the seller fails to perform as promised).

10. Article 5 defines an "issuer" as "a bank or other person that issues a letter of credit, ... not includ[ing] an individual who makes an engagement for personal, family, or household purposes." U.C.C. \& 5-102(a)(9) (1995); see also UCP500, supra note 1, art. 2; International Chamber of Commerce, Pub. No. 590, International Standby PraCTICES ISP98 R. 2.01(a) (1998) [hereinafter ISP98].

11. See 1 John F. Dolan, The law of Letters of Credit: Commercial and STANDBY CREDITS TI 2.01 (rev. ed. 2003).

12. See Gerald T. McLaughlin, Exploring Boundaries: A Legal and Structural Analysis of the Independence Principle of Letter of Credit Law, 119 BANkING L.J. 501, 506-07 (2002).

13. See infra text accompanying notes $43-46$.

14. See infra text accompanying notes 47-51. 
tion to pay money between a borrower and a lender, ${ }^{15}$ or a contract for the purchase and sale of goods or services between a buyer and a seller. ${ }^{16}$

The second undertaking is between the buyer (in this context, the "applicant"17) and the letter of credit issuer, in which the issuer agrees to issue the letter of credit in favor of the seller (in this context, the "beneficiary"18) in exchange for the applicant's agreement to reimburse the issuer for any amounts the issuer disburses to the beneficiary on the letter of credit. ${ }^{19}$ Issuers often require applicants to pledge collateral to secure their promise to reimburse the issuer if the issuer has to honor the letter of credit. ${ }^{20}$

The third undertaking, the letter of credit itself, is the issuer's promise to pay the beneficiary when the beneficiary presents certain required documents $^{21}$ or demands payment. ${ }^{22}$ This third undertaking is independent of the other two:

Rights and obligations of an issuer to a beneficiary ... under a letter of credit are independent of the existence, performance, or nonperformance of a contract or arrangement out of which the letter of credit arises or which underlies it, including contracts or arrangements between the issuer and the applicant and between the applicant and the beneficiary. ${ }^{23}$

15. See, e.g., Republic Nat'l Bank v. Northwest Nat'l Bank, 578 S.W.2d 109 (Tex. 1979) (involving a standby letter of credit issued against proof of default on a promissory note).

16. See, e.g., B.E.I. Int'l, Inc. v. Thai Military Bank, 978 F.2d 440 (8th Cir. 1992) (involving a standby letter of credit issued to "counterguarantee" the applicant's obligation to produce and deliver weapon systems to the beneficiary of the standby letter).

17. Article 5 defines an "applicant" to be someone "at whose request or for whose account a letter of credit is issued," including someone "who requests an issuer to issue a letter of credit on behalf of another if the person making the request undertakes an obligation to reimburse the issuer." U.C.C. \$ 5-102(a)(2) (1995); see also UCP500, supra note 1 , art. 2; ISP98, supra note 10, R. 1.09(a).

18. Article 5 defines "beneficiary" to be "a person who under the terms of a letter of credit is entitled to have its complying presentation honored," including "a person to whom drawing rights have been transferred under a transferable letter of credit." U.C.C. $\$ 5-102(\mathrm{a})(3)$; see also UCP500, supra note 1, art. 2(i); ISP98, supra note 10, R. 1.09(a), $1.11(\mathrm{c})(\mathrm{i})$.

19. See McLaughlin, supra note 12 , at 507-08.

20. See 1 DoLAN, supra note 11, II $9.02[1]$.

21. See McCormack v. Citibank, N.A., 100 F.3d 532, 537 (8th Cir. 1996) ("To draw on a documentary letter of credit, the beneficiary of that credit must present the issuing bank with whatever documentation that is called for by the express terms of the credit."); see, e.g., Republic Nat'l Bank v. Northwest Nat'l Bank, 578 S.W.2d 109, 116 (Tex. 1979) (holding that the issuer was obliged to honor a documentary letter of credit that conditioned payment on "presentation of a properly drawn draft [and] four specific documents" where, in fact, the successor beneficiary had presented a properly drawn draft and the four specified documents).

22. See McCormack, 100 F.3d at 537-38 ("[T] draw on a clean letter of credit, the beneficiary must merely demand payment; no documentation, other than perhaps a written demand for payment, is required."); see, e.g., id. at 539-40 (finding that the bank had properly honored the beneficiary's demand for payment, where the letter of credit provided that the bank would pay the beneficiary "upon receipt of your first written demand .... either in the form of a tested telex or a letter"). See generally 1 DoLAN, supra note 11, II $2.05[1]$ \& G-8.

23. U.C.C. $\$ 5-103$ (d); see also UCP500, supra note 1, art. 3; ISP98, supra note 10, R. 1.07. See generally McLaughlin, supra note 12, at 508-09; Gerald T. McLaughlin, Letters of 
As a result, an issuer normally ${ }^{24}$ cannot refuse to honor a beneficiary's conforming presentation ${ }^{25}$ (or, in the case of a "clean" letter of credit, a beneficiary's draft or demand for payment ${ }^{26}$ ) based on some infirmity in the beneficiary's performance of its contract with the applicant ${ }^{27}$ or in the

Credit and Illegal Contracts: The Limits of the Independence Principle, 48 Онго Sт. L.J. 1197, 1206-07 (1989).

"Since by its very nature a letter of credit is ... independent of the underlying transaction, it necessarily follows that there is no legal distinction between a letter of credit issued before, after, or concomitantly with the consummation of the underlying transaction." $R e$ public Nat'l Bank, 578 S.W.2d at 116.

24. Article 5 recognizes two limited exceptions to the general rule prohibiting an issuer from refusing to honor a conforming presentation based on some infirmity in the beneficiary's performance of its contract with the applicant. Section 5-109(a)(2) permits an issuer to dishonor a facially conforming presentation if the issuer has a good faith belief that honoring the presentation "would facilitate a material fraud by the beneficiary on the issuer or applicant." U.C.C. \$ 5-109(a)(2); see, e.g., Boston Hides \& Furs, Ltd. v. Sumitomo Bank, Ltd., 870 F. Supp. 1153, 1164-65 (D. Mass. 1994); Prairie State Bank v. Universal Bonding Ins. Co., 953 P.2d 1047, 1052-53 (Kan. Ct. App. 1998); Takeo Co. v. Mead Paper, Inc., 611 N.Y.S.2d 543, 545 (N.Y. App. Div. 1994) (all applying section 5109(a)(2)'s predecessor, former section 5-114(2)(b)); see also Sztejn v. J. Henry Schroder Banking Corp., 31 N.Y.S.2d 631, 634 (N.Y. Sup. Ct. 1941) (applying pre-Code common law to reach the same result). Section 5-109(b) also entitles an applicant to seek an injunction against the issuer from a court of competent jurisdiction if the applicant can show that "honor of the presentation would facilitate a material fraud by the beneficiary on the ... applicant." U.C.C. \$ 5-109(b). See generally 1 Dolan, supra note 11, ף] 4.03[6][b].

The UCP500 are silent on the issue of fraud; whereas the ISP98 explicitly defer to other applicable law on questions of fraud, abuse, and similar defenses to honor. See ISP98, supra note 10, R. 1.05 (c).

25. Article 5 defines "presentation" as "delivery of a document to an issuer or nominated person for honor or giving of value under a letter of credit." U.C.C. \$ 5-102(12); see also ISP98, supra note 10, R. 1.09(a), 3.02. "Honor," in turn, "means performance of the issuer's undertaking in the letter of credit to pay or deliver an item of value." U.C.C. § 5102(8); see also ISP98, supra note 10, R. 2.01(b).

26. See supra note 22.

27. See, e.g., Provident Bank of Md. v. Travelers Prop. Cas. Corp., 236 F.3d 138, 147 (4th Cir. 2000); In re Slamans, 69 F.3d 468, 474 (10th Cir. 1995); Dibrell Bros. Int'l v. Banca Nazionale del Lavoro, 38 F.3d 1571, 1579 (11th Cir. 1994); Alaska Textile Co. v. Chase Manhattan Bank, 982 F.2d 813, 815 (2d Cir. 1992); Tudor Dev. Group, Inc. v. United States Fid. \& Guar. Co., 968 F.2d 357, 360 (3d Cir. 1992); San Diego Gas \& Elec. Co. v. Bank Leumi, 50 Cal. Rptr. 2d 20, 24 (Cal. Ct. App. 1996); Strozzo v. Sea Island Bank, 521 S.E.2d 392, 396-97 (Ga. Ct. App. 1999); Vill. of Long Grove v. Austin Bank of Chi., 644 N.E.2d 456, 458-59 (Ill. App. Ct. 1994). See generally 1 Dolan, supra note 11, II 4.03[6].

The rule of the independence of the letter of credit from the underlying transaction is based on two policy considerations. First, the issuing bank can assume no liability for the performance of the underlying contract because it has no control over making the underlying contract or over selection of the beneficiary. Second, the letter of credit would lose its commercial vitality if, before honoring drafts, the issuing bank were obliged to look beyond the terms of the letter of credit to the underlying contractual controversy between its customer and the beneficiary. Whatever the bank pays upon the letter of credit it can recover from its customer ordinarily. If the customer feels that the beneficiary was not entitled to that amount, then these parties can litigate under their contract. In fact, one of the main purposes of the letter of credit is to place the seller in this stronger position of having the funds while the parties litigate their underlying contract disputes.

Where the issuer of the letter of credit dishonors a proper demand for payment, ... and therefore further presentation of documents is excused, it is consistent with the independence principle to regard ... as beyond the purview of the bank's inquiry rights ... any proof that the beneficiary suffered a 
applicant's performance of its contract with the issuer. ${ }^{28}$

The issuer's agreement to pay the beneficiary out of the issuer's own funds - with or without the intervention of a confirming, negotiating, or paying bank ${ }^{29}$-is the key to the letter of credit. Indeed, the letter of credit's "effectiveness ... as a commercial device depends upon prompt

loss on the underlying agreement. If the documents called for by the letter of credit had been produced, the bank would have no right to inquire into plaintiff's actual costs of production or profit margins. When the issuing bank breaches the credit promise, there is no reason to enlarge the bank's entitlement to challenge the beneficiary. The way to make the beneficiary whole and provide it with the full benefit of the credit promise is to require the issuer to pay damages in the face amount of the credit balance. Any other interpretation as to damages would defeat the basic purpose of such a letter of credit of providing a means of assuring payment cheaply by eliminating the need for, or the power of, the issuer to police the underlying transaction. This approach preserves the efficacy of the letter of credit in commercial transactions to provide the seller with a means of obtaining prompt payment.

Ross Bicycles, Inc. v. Citibank, N.A., 613 N.Y.S.2d 538, 540-41 (N.Y. Sup. Ct. 1994) (citations omitted).

28. Thus, for example:

From the point of view of the beneficiaries, AMC and Liberty Mutual, the way that Bank One settled its accounts with Bergner was of no importance, either legal or practical. As soon as Bank One issued the irrevocable letters in favor of each beneficiary (for a fee, as Bergner reminds us), it assumed the obligation of paying upon a draft supported by documents that conformed to the terms of the credit. Thus, when AMC presented its draft with conforming documents to Bank One on July 19, 1991, Bank One was required to pay AMC the full $\$ 31,207,000$ that the letter of credit then provided, whether or not Bergner gave it a red cent. If Bergner did not comply with its own agreement with Bank One, under which it was required to give the bank the amount of the draw either before or at the time of the payment to the beneficiary, then Bank One would have had a perfectly good contract action against Bergner, but it would have had no defense against honoring the beneficiary's demand.

In re P.A. Bergner \& Co., 140 F.3d 1111, 1114-15 (7th Cir. 1998); see also, e.g., Generale Bank v. Czarnikow-Rionda Sugar Trading, Inc., 47 F. Supp. 2d 477, 479-80 (S.D.N.Y. 1999) ("This 'independence principle' is most often expressed to distinguish actual letters of credit from the underlying contracts between buyers and sellers. It is just as clear that letters of credit are separate from the contracts between the buyers/applicants and the issuing banks." (citation omitted)).

29. A letter of credit transaction may involve more parties and more undertakings than those described thus far. Article 5 also recognizes "advisers," who "at the request of the issuer . . notify the beneficiary that a letter of credit has been issued," U.C.C. § 5102(a)(1); see also UCP500, supra note 1, art. 7; ISP98, supra note 10, R. 2.05(a), "confirmers," who undertake "at the request or with the consent of the issuer, to honor a presentation under a letter of credit," U.C.C. \$ 5-102(a)(4); see also UCP500, supra note 1, art. 9; ISP98, supra note 10, R. 1.09(a), and "nominated persons," who "the issuer (i) designates or authorizes to pay, accept, negotiate, or otherwise give value under the letter of credit and (ii) undertakes by agreement or custom and practice to reimburse," U.C.C. \$ 5-102(a)(11); see also UCP500, supra note 1, art. 10(b)(i); ISP98, supra note 10, R. 2.04(a). A "nominated person" generally serves as either a "negotiating bank" or a "paying bank":

A negotiating bank, often appointed simply to expedite payment, is authorized, at its option, to act as a confirming bank and is entitled to reimbursement plus a fee from the issuer when it does so. ...

A paying bank is a bank used as a conduit to get the issuing bank's funds into the hands of the beneficiary. A paying bank may be designated by an issuer who wishes to honor the letter of credit but lacks the type or amount of currency that honoring the letter of credit requires.... The paying bank 
and inevitable honor of the beneficiary's conforming presentation." 30 So, what happens when an issuer derails the inevitability of prompt honor by clearly and unconditionally manifesting its intent not to honor, or its inability to honor, a conforming presentation or draft when and as promised?

\section{THE CONCEPTUAL BACKGROUND}

Part II of this article will explore how the doctrine of anticipatory repudiation applies to letters of credit. First, however, it may be helpful to review key aspects of the law of letters of credit and of the doctrine of anticipatory repudiation. ${ }^{31}$

\section{A. Governing Law}

Subject to an enforceable agreement to the contrary, ${ }^{32}$ Article 5 of the Uniform Commercial Code governs letters of credit issued in the United States, ${ }^{33}$ as well as, in many cases, letters of credit issued outside the United States in favor of a beneficiary who resides in the United States ${ }^{34}$

disburses the funds to the beneficiary, then diminishes the issuing bank's account held with the paying bank accordingly.

George P. Graham, Note, International Commercial Letters of Credit and Choice of Law: So Whose Law Should Apply Anyway?, 47 WAYNE L. REv. 201, 209-10 (2001) (footnotes omitted); see also U.C.C. \& 5-102(a)(11) \& cmt. 7; UCP500, supra note 1, arts. 9-10; ISP98, supra note 10, R. 2.04(a). See generally 1 Dolan, supra note 11, Il 2.08[3]. Because this article is primarily about anticipatory repudiation of letters of credit, and not about the mechanics of their creation or honor, the remainder of the discussion makes the simplifying assumption that, unless the facts clearly indicate otherwise, any letter of credit transaction at issue involves only an applicant, an issuer, and a beneficiary.

30. 1 DoLAN, supra note 11, 9 9.02[1].

31. For more thorough discussions of letter of credit law, see, for example, $1 \& 2$ DoLan, supra note 11, and Brooke Wunnicke et al., STANDby and Commercial LetTERS OF CREDIT (3d ed. 2000 \& Supp. 2002). For a more thorough discussion of the doctrine of anticipatory repudiation not restricted to the context of letters of credit, see Keith A. Rowley, A Brief History of Anticipatory Repudiation in American Contract Law, 69 U. CIN. L. REv. 565 (2001), and the sources cited therein.

32. See U.C.C. \& 5-116(a) (1995) ("The liability of an issuer ... is governed by the law of the jurisdiction chosen by an agreement ... authenticated by the affected parties ... or by a provision in the[ir] letter of credit, confirmation, or other undertaking. The jurisdiction whose law is chosen need not bear any relation to the transaction."); see also UCP500, supra note 1 , art. 1; ISP98, supra note 10, R. 1.01(b).

33. U.C.C. \$ 5-116(b) ("Unless [section 5-116(a)] applies, the liability of an issuer . . is governed by the law of the jurisdiction in which the [issuer] is located. ..."); see, e.g., Bank of Joliet v. Firstar Bank Milwaukee, N.A., No. 96 C 1145, 1997 U.S. Dist. LEXIS 15384 , at $* 17-18$ (N.D. Ill. Sept. 30, 1997) (applying Wisconsin law, to the extent it did not conflict with the UCP500, supra note 1, to ascertain the liability of the Wisconsin-domiciled bank where the parties failed to agree to apply the law of any other jurisdiction to those issues not resolved by the UCP500). See generally 1 Dolan, supra note 11, II 4.02; Franck Chantayan, Choice of Law Under Revised Article 5 of the Uniform Commercial Code-\$ 5116, 14 ST. JoHN's J. LEG. Comm. 199 (1999); Graham, supra note 29, at 213.

34. For letters of credit issued outside of the United States in favor of American beneficiaries that are not subject to the Convention, United Nations Convention on Independent Guarantees and Stand-By Letters of Credit, Dec. 11, 1995, 1995 U.N.Y.B. 1358, at http://www.uncitral.org/english/texts/payments/guarantees.htm (last visited Nov. 3, 2003) [hereinafter U.N. Convention], and in which the parties have not explicitly chosen their governing law, American courts have tended to apply the law of the issuer's residence in 
and letters of credit issued outside the United States in which the parties expressly choose to have their agreement governed by Article 5.35 The version of Article 5 currently in effect in every state except Wisconsin ${ }^{36}$

cases in which the court has concluded that payment is excused and the law of the beneficiary's residence-i.e., Article 5-in cases in which the court has concluded that payment is not excused. See Graham, supra note 29, at 213-22, and cases cited therein.

35. See U.C.C. $\$$ 5-116(a).

The U.N. Convention takes a similar approach to the law governing international standby letters of credit. Subject to an enforceable agreement to the contrary, see U.N. Convention, supra note 34, arts. 1(1), 1(3), 21(a), the Convention governs a letter of credit if the applicant's, beneficiary's, issuer's, and confirming bank's (if any) most "relevant" places of business or residences are in at least two different countries, see id. art. 4, and either the issuer is located in a country that is a party to the Convention, see id. art. 1(a), or "the rules of private international law" lead to applying the law of a country that is a party to the Convention, see id. art. 1(b). The Convention also governs a letter of credit if the parties, notwithstanding their residence, have expressly chosen the Convention to govern the undertaking. See id. arts. 1(2), 21. See generally Richard F. Dole, Jr., The Essence of a Letter of Credit Under Revised U.C.C. Article 5: Permissible and Impermissible Nondocumentary Conditions Affecting Honor, 35 Hous. L. REv. 1079, 1089-90 (1998). As of November 3, 2003, only Belarus, Ecuador, El Salvador, Kuwait, Panama, and Tunisia had ratified the Convention. See United Nations Commission on International Trade Law (UNCITRAL), Status of Conventions and Model Laws: United Nations Convention on Independent Guarantees and Stand-By Letters of Credit, available at http://www.uncitral.org/ english/status/status-e.htm (last visited Nov. 3, 2003). The United States has signed the Convention, but has not yet ratified it. See id. For an overview of the Convention, see Filip De Ly, The UN Convention on Independent Guarantees and Stand-By Letters of Credit, 33 INT'L LAW. 831 (1999).

36. Ala. Code § 7-5-101 (1997); Alaska Stat. § 45.05.101 (Michie 2001); Ariz. Rev. Stat. AnN. \$ 47-5101 (West 1997); Ark. Code AnN. § 4-5-101 (Michie 2001); Cal. Com. Code $\S 5101$ (West 2002); Colo. Rev. Stat. AnN. § 4-5-101 (West 2001); Conn. Gen. Stat. Ann. § 42a-5-101 (West Supp. 2002); Del. Code AnN. tit. 6, § 5-101 (1999); D.C. Code AnN. $\$ 28: 5-101$ (2001); Fla. Stat. Ann. \$675.101 (West Supp. 2002); GA. Code Ann. \$ 11-5-101 (Harrison Supp. 2002); Haw. Rev. Stat. \$ 490:5-101 (Michie 1999); IDAHo Code $\$ 28-5-101$ (Michie 2001); Ill. CoMp. Stat. ch. 810, II 5/5-101 (West 2002); Ind. Code AnN. § 26-1-5.1-101 (Michie Supp. 2002); Iowa Code AnN. § 554.5101 (West 2001); Kan. Stat. Ann. \$ 84-5-101 (1996); Ky. Rev. Stat. AnN. \$ 355.5-101 (Michie 2002); La. Rev. Stat. AnN. $§ 10: 5-101$ (West 2001); Me. Rev. Stat. Ann. tit. 11, § 5-1101 (West Supp. 2001); MD. Code Ann. Com. Law II \$ 5-101 (2002); Mass. Gen. Laws AnN. ch. 106, §5-101 (West 1999); Mich. Comp. Laws AnN. $\$ 440.5101$ (West Supp. 2002); Minn. Stat. Ann. $\$ 336.5-101$ (West 2002); Miss. Code Ann. § 75-5-101 (1999); Mo. AnN. Stat. § 400.5-101 (West 2002); Mont. Code AnN. § 30-5-101 (2001); Neb. Rev. STat. § 5101 (2000); Nev. Rev. Stat. AnN. 104.5101 (Michie 2000); N.H. Rev. Stat. AnN. \$ 382 A:5-101 (2002); N.J. Stat. Ann. § 12A:5-101 (West Supp. 2002); N.M. STAt. AnN. § 55-5101 (Michie Supp. 2001); N.Y. U.C.C. $\$$ 5-101 (McKinney 2001); N.C. GEN. STAT. § 25-5101 (2001); N.D. Cenr. Code § 41-05-01 (1999); Ohio Rev. Code Ann. § 1305.01 (West Supp. 2001); Okla. Stat. ANN. tit. 12A, \$ 5-101 (West 1998); Or. Rev. Stat. § 75.1010 (1999); 13 Pa. Cons. Stat. AnN. $\$ 5101$ (West Supp. 2002); R.I. Gen. Laws § 6A-5-101 (2001); S.C. Code AnN. \& 36-5-101 (Law. Co-op Supp. 2001); S.D. Codified Laws $§ 57 A-$ 5-101 (Michie 2002); Tenn. Code Ann. \$ 47-5-101 (2001); Tex. Bus. \& Com. Code AnN. $\S 5.101$ (Vernon 2002); Utah Code AnN. § 70A-5-101 (2001); VT. STAT. AnN. tit. 9A, § 5101 (2001); VA. Code AnN. \$ 8.5A-101 (Michie 2001); Wash. Rev. Code AnN. $\$ 62 A .5-$ 101 (West Supp. 2002); W. VA. Code $\S 46-5-101$ (2001); Wyo. Stat. AnN. $\$ 34.1-5-101$ (Michie 2001).

Wisconsin's Article 5 is still based on the 1962 version of uniform Article 5. See WIS. STAT. ANN. \$§ 405.101-405.118 (West 1995); U.C.C. $\$ \S 5-101$ to -117 (1962). Despite a unanimous recommendation from the appropriate committee, Wisconsin Senate Bill 203 ("An Act to ... adopt[ ] revised Article 5 of the Uniform Commercial Code ....") did not pass during the 2001-02 legislative session. See http://www.legis.state.wi.us/2001/data/ SB203hst.html (last visited Nov. 3, 2003). 
explicitly recognizes the ability of letter of credit parties to expressly incorporate the current Uniform Customs and Practice for Documentary Credits ("UCP"), ${ }^{37}$ promulgated by the International Chamber of Commerce. ${ }^{38}$ If the parties expressly incorporate the UCP into their letter of credit (which most $\mathrm{do}^{39}$ - often as boilerplate, rather than as a negotiated

37. UCP500, supra note 1. UCP500 replaced the 1983 revisions to the UCP. INTERnational Chamber of Commerce, Pub. No. 400, Uniform Customs and Practice For Documentary CRedits (1983) [hereinafter UCP400]. UCP400 replaced the 1974 revision. International Chamber of Commerce, Pub. No. 290, Uniform Customs and Practice for Documentary Credits (1974) [hereinafter UCP290]. The ICC issued prior versions in 1962, 1951, and 1933. InTERnATIONAL CHAMBER OF CommerCE, Pub. No. 222, Uniform Customs and Practice for Documentary Credits (1962); International Chamber of Commerce, Pub. No. 151, Uniform Customs and Practice for Documentary Credits (1951); International Chamber of Commerce, Pub. No. 74, Uniform Customs and Practice for Documentary Credits (1933).

For an overview of the UCP500 and a discussion of their interaction with former Article 5 and Revised Article 5, see 6B WiLliam D. HaWkLAND \& FrederiCK H. MILLER, UNIform Commercial Code Series [Rev.] § 5-103:3 (1999 \& Supp. 2002); 6B William D. Hawkland \& Tom L. Holland, Uniform Commercial Code Series \& 5-102:7 (1999 \& Supp. 2002); and Katherine A. Barski, Letters of Credit: A Comparison of Article 5 of the Uniform Commercial Code and the Uniform Customs and Practice for Documentary Credits, 41 Loy. L. REv. 735 (1996). See generally Dale Joseph Gilsinger, Annotation, Validity, Construction, and Application of the Uniform Customs and Practice for Documentary Credits (UCP), 56 A.L.R.5th 565 (1998).

38. See U.C.C. \$ 5-116(c) (1995); see, e.g., Mantua Mfg. Co. v. Commerce Exch. Bank, 661 N.E.2d 161, 165 (Ohio 1996) ("[W]hen a letter of credit is subject to the UCP and there is a direct conflict between a provision of the UCP and an analogous provision of [Article 5], the UCP terms replace those of [Article 5], unless that replacement violates the conditions of [current section 1-102(3)]."); Vest v. Pilot Point Nat'l Bank, 996 S.W.2d 9, 15 (Tex. Ct. App.-Fort Worth 1999, pet. denied) ("The UCP . . . can have the force of law when incorporated into a letter of credit."); see also Voest-Alpine Trading Co. v. Bank of China, 167 F. Supp. 2d 940, 944 (S.D. Tex. 2000) ("Where parties explicitly refer to the UCP500 in their contracts, the UCP has been interpreted to apply to the transaction."), aff'd, $288 \mathrm{~F} .3 \mathrm{~d}$ 262 (5th Cir. 2002). See generally Chantayan, supra note 33, at 207-08.

While the version of Article 5 still in effect in Wisconsin does not explicitly address the UCP, it does recognize that Article 5 is not the exclusive source of rules governing letters of credit, see WIS. STAT. ANN. $\$ 405.102(3)$, and that the parties may vary most provisions of Article 5 by agreement, see id. $\$ 401.102(3)$. Decisions applying Wisconsin's version of Article 5 suggest that courts consider the UCP to be a valid modification if incorporated into the letter of credit by reference. See, e.g., In re P.A. Bergner \& Co., 140 F.3d 1111, 1114-15 (7th Cir. 1998) (applying Wisconsin law and holding that a irrevocable standby letter of credit that, inter alia, specified it was subject to UCP400 was "governed by" UCP400); Datapoint Corp. v. M \& I Bank of Hilldale, 665 F. Supp. 722, 725-27 (W.D. Wis. 1987) (applying article 16 of the UCP400 to determine whether the issuer had timely notified the beneficiary that it was dishonoring the beneficiary's draft); see also, e.g., Beathard v. Chic. Football Club, Inc., 419 F. Supp. 1133, 1139 (N.D. Ill. 1976) (holding that, where the language of letters of credit at issue did not reveal whether they were revocable or irrevocable, Article 1 of the 1962 version of the UCP-which was incorporated by reference into the letter of credit, provided that the letters must be deemed to be revocable).

Because the UCP do not contain a choice of law provision-other than Article 1, which states only that the UCP will apply if the parties expressly incorporate them into their letter of credit, see UCP500, supra note 1, art. 1-parties cannot "opt out" of Article 5 by "opting in" to the UCP. See U.C.C. $\$ 5-103 \mathrm{cmt}$. 2 ("Since incorporation of the UCP avoids only 'conflicting' Article 5 rules, parties who do not wish to be governed by the nonconflicting provisions of Article 5 must normally either adopt the law of a jurisdiction other than a State of the United States or state explicitly the rule that is to govern."). See generally Graham, supra note 29, at 213.

39. See Hanil Bank v. PT. Bank Negara Indon., 41 U.C.C. Rep. Serv. 2d 618, 621 (S.D.N.Y. 2000) ("[T]he UCP commonly governs letters of credit by virtue of its incorpora- 
term), then the UCP will govern the letter of credit to the extent the UCP and Article 5 conflict, except with respect to those Article 5 protections the parties may not agree to vary. ${ }^{40}$ Even if the parties do not explicitly incorporate the UCP, courts will look to the UCP for evidence of custom and usage. ${ }^{41}$ And, where the issue presented is not resolved by applying

tion into most letters of credit."); UBAF Arab Am. Bank v. New World Research Corp., 571 N.Y.S.2d 223, 223 (N.Y. App. Div. 1991) (acknowledging that "nearly all international letters of credit" incorporate the UCP); Prefatory Note to U.C.C. Revised Article 5 (1995) (recognizing that the UCP are "used in most international letters of credit and in many domestic letters of credit" and that the UCP are "usually incorporated into letters of credit, particularly international letters of credit"); U.C.C. $\$ 5-103 \mathrm{cmt}$. 2 ("Many letters of credit specifically adopt the UCP as applicable to the particular transaction.").

40. The U.C.C. explains that:

Except as otherwise provided in this subsection, the liability of an issuer ... is governed by any rules of custom or practice, such as the [UCP], to which the letter of credit ... or other undertaking is expressly made subject. If (i) this chapter would govern the liability of an issuer ... under [section 5-116(a) or (b)], (ii) the relevant undertaking incorporates [the UCP], and (iii) there is conflict between [Article 5] and th[e UCP] as applied to that undertaking, ... except to the extent of any conflict with [U.C.C. $\$ \$ 5-102(a)(9)-(10), 5-$ 103(a), (c), (d), 5-106(d), 5-114(d), 5-117(d)].

U.C.C. § 5-116(c); see, e.g., Mantua Mfg., 661 N.E.2d at 165 (applying article 10(d) of UCP400, requiring only the consent of the issuing bank, confirming bank (if any), and beneficiary prior to amending or canceling an irrevocable letter of credit, rather than former U.C.C. \$ 5-106(2), which required the applicant's consent, as well); Vest, 996 S.W.2d at 14-15 (applying the "reasonable care" standard of UCP500 art. 13, instead of the "strict compliance" standard developed by the Texas courts under former U.C.C. \$ 5-109(2), to determine whether the issuer wrongfully honored a demand that contained a documentary discrepancy). See generally Dole, supra note 35, at 1088. Courts should not assume a conflict between Revised Article 5 and the UCP in the absence of an express one. See U.C.C. $\S 5-103 \mathrm{cmt}$. 2. For a discussion of Revised Article 5's nonvariable provisions, see Sandra Stern, Varying Article 5 of the UCC by Agreement, 114 BANKING L.J. 516, 517-21 (1997).

41. See, e.g., Mantua Mfg., 661 N.E.2d at 166 (stating that, even if the UCP were not expressly incorporated by the parties, the UCP are "a guide to trade usage in letter of credit transactions").

Because the International Chamber of Commerce drafted the UCP500 primarily with commercial letters of credit in mind, and because some have perceived the UCP not to apply well to standby letters of credit, see, e.g., James E. Byrne, Why the ISP Should be Used for Standbys, DocumentaRy CRedit WORLD, Jan. 2000, at 23, the Institute of International Banking Law and Practice, Inc. drafted, and the International Chamber of Commerce has endorsed, the 1998 International Standby Practices ("ISP98"). ISP98, supra note 10 . For an authoritative analysis of ISP98, see JAMEs E. BYRNe, The OfFICIAL COMmentary on the International Standby Practices (James G. Barnes ed. 1998). For a thoughtful critique of ISP98, see John F. Dolan, Analyzing Bank Drafted Standby Letter of Credit Rules: The International Standby Practice (ISP98), 45 WAYNE L. Rev. 1865 (2000).

The 1995 version of Article 5, which predates the ISP98 by three years, obviously makes no reference to them. Nor, less obviously, do the text or commentary accompanying any state's enactment of Revised Article 5 since the ICC promulgated the ISP98. Indeed, the only statutory reference to ISP98 as of the time of this writing appears in a Maine statute permitting an employer to post an irrevocable standby letter of credit as proof of solvency and ability to pay workers' compensation claims. See ME. Rev. Stat. Ann. tit. 39-A, $\S 403(3)(\mathrm{A})$ (West 2001) ("To the extent not inconsistent with state law, the letter of credit is subject to and governed by the International Standby Practices 1998 or successor practices governing standby letters of credit duly adopted by the International Chamber of Commerce."). The ISP98 have been mentioned in only one case reported as of the time of this writing. See Nissho Iwai Eur. PLC v. Korea First Bank, 782 N.E.2d 55, 61 (N.Y. 2002) (citing ISP98 R. 1.10[c][ii] for the proposition that the meaning of "revolving" in the letter of credit in question "should be derived from the context in which the term is used"). 
Article 5 and the UCP (if the latter are incorporated by agreement of the parties), or by reference to the UCP (if they are not incorporated by agreement of the parties), courts will turn to common law. ${ }^{42}$

\section{B. Commercial and Standby Letters of Credit}

Letters of credit come in two basic varieties: commercial and standby. In a typical commercial letter of credit transaction, a buyer (the applicant) induces its bank (the issuer) to irrevocably obligate itself to pay a seller (the beneficiary) a stated amount of money, at a stated time, on receipt of stated documents-typically, the seller's invoice and shipping documents. ${ }^{43}$ If the beneficiary presents conforming documents at or by the stated time, the issuer must honor the letter of credit or answer to the beneficiary for the issuer's wrongful dishonor. ${ }^{44}$ The issuer's obligation to the beneficiary is not conditioned on the beneficiary's performance of its underlying contract with the applicant. ${ }^{45}$ Nor is it conditioned on the applicant's performance of its contract with the beneficiary. ${ }^{46}$

Nonetheless, subject to Article 5's prohibitions on contractually varying certain terms, see supra note 40, parties should be able to incorporate the ISP98 into their standby letters of credit, see U.C.C. $\$ 5-103$ (c) (permitting the parties to vary most provisions of Article 5 "by agreement or by a provision stated or incorporated by reference in an undertaking"), and have begun doing so at least in certain circles, see James E. Byrne, Overview of Letter of Credit Law \& Practice in 2001, in ANnual Survey of LetTers of Credit 7-8 (James E. Byrne \& Christopher S. Brynes eds., 2002) (reporting anectodal evidence of widespread use of ISP98). And, where the parties have not explicitly incorporated ISP98 into their standbys, courts should recognize ISP98 as evidence of custom and usage in international standbys.

42. See, e.g., Hyosung Am., Inc. v. Sumagh Textile Co., 25 F. Supp. 2d 376, 385 \& n.11 (S.D.N.Y. 1998) (recognizing an applicant's common law right to assert a fraud claim against the beneficiary after the letter of credit had been drawn down and the applicant's account had been debited, because such an exception did not conflict with the UCP, which the parties had chosen as governing law under former N.Y. U.C.C. $\$ 5-102(4)$ ), aff'd, 189 F.3d 461 (2d Cir. 1999); Leonard A. Feinberg, Inc. v. Cent. Asia Capital Corp., 974 F. Supp. 822, 835-38 (E.D. Pa. 1997) (applying common law to ascertain the proper classification for a party to the letter of credit transaction that did not fit within any of the party types denominated in former Article 5 or the UCP and the effect of a so-called "red clause"); First State Bank v. Diamond Plastics Corp., 891 P.2d 1262, 1271-72 (Okla. 1995) (holding that a letter of credit beneficiary could assert equitable estoppel to bar the issuer from refusing to honor drafts which were consistent with draf:s the issuer had previously honored against letters of credit containing similar language and requirements as the ones at issue); see also infra note 87.

43. See, e.g., Alaska Textile Co. v. Chase Manhattan Bank, N.A., 982 F.2d 813, 817 (2d Cir. 1992) ("Alaska Textile Co. . . . is a New York-based textile company that exports fabric from India. Lloyd Williams Fashions, Inc., a manufacturer of women's clothing, contracted with Alaska in early 1988 to buy several thousand yards of Indian silk . . . to be delivered to Lloyd's facility in Hong Kong. To make payment, Lloyd arranged for . . . Chase Manhattan Bank to issue two letters of credit in favor of Alaska, for $\$ 82,500$ and $\$ 47,141.25$, respectively."); see also supra notes 10-22 and accompanying text. See generally Henry D. Gabriel, Standby Letters of Credit: Does the Risk Outweigh the Benefits?, 1988 Colum. Bus. L. REv. 705, 708-09.

44. See U.C.C. $\$$ 5-108(a); supra notes $23-32$ and accompanying text. See generally 1 DolAN, supra note 11, II 6.01; WUNNICKE ET AL., supra note $31, \S 2.02$.

45. See supra note 27.

46. See State ex rel. Hwy. \& Transp. Comm'n v. Morganstein, 703 S.W.2d 894, 898 (Mo. 1986) ("No default in performance of the underlying obligation by the [applicant] is 
The issuer's obligation to the beneficiary of a standby letter of credit, by contrast, is conditioned on the applicant's performance of-or, more precisely, the beneficiary's presentation of documents evidencing the applicant's failure to perform-its underlying contract with the beneficiary. ${ }^{47}$ Thus,

[w]hile the applicant is performing, or preparing to perform, its obligation on the contract, the beneficiary, who awaits that performance, has the benefit of a separate promise (from the issuer) that if the applicant defaults, the issuer will pay the beneficiary an amount of money secured by the letter of credit. 48

In a typical standby letter of credit transaction, the applicant induces the issuer to irrevocably obligate itself to pay the beneficiary up to a stated amount of money, at or before a stated time, on receipt of documentation-sometimes simply a self-serving statement by the beneficiary 49 -evidencing the applicant's default on the underlying obligation..$^{50}$ If (but only if) the beneficiary can satisfy the issuer that the applicant has failed to pay as promised, the issuer must pay the beneficiary out of the issuer's own funds. ${ }^{51}$

necessary to trigger the obligation of the issuer to pay under the letter."). See generally WUNNICKE ET AL., supra note $31, \S 2.06$.

47. See Gabriel, supra note 43, at 709 ("In contrast to [commercial] letters of credit, the rights of a standby letter of credit beneficiary are activated only after the [applicant] has defaulted on the underlying contract."). 1998).

48. S. Energy Homes, Inc. v. AmSouth Bank of Ala., 709 So. 2d 1180, 1184 (Ala.

For example:

The effect of standby letters of credit like these is to put the issuer (Bank One) itself behind the [applicant]'s (Bergner's) promises to pay. As long as Bergner paid those with which it contracted, the standby letters of credit did not come into play. If, however, one of the events entitling a beneficiary to draw on a letter of credit occurred, then the beneficiary was entitled to go straight to Bank One to collect its money, without worrying about Bergner's financial health. Bank One, in turn, promised to honor a demand from either beneficiary that conformed to the letters of credit, no matter what defenses Bergner may have had against either AMC's or Liberty Mutual's request for funds.

In re P.A. Bergner \& Co., 140 F.3d 1111, 1115 (7th Cir. 1998).

49. See 1 Dolan, supra note 11, II 1.07[2]; WUNNICKE ET AL., supra note 31, § 13.10.

50. See, e.g., Bank One, Tex., N.A. v. Little, 978 S.W.2d 272, 277 n.8 (Tex. App.-Fort Worth 1998, pet denied) (observing that the standby letter of credit issued by NCNB at the request of Justin, a boot manufacturer, in favor of Mitco, a supplier of ostrich skins "did not actually represent payment for the skins. It merely represented that Mitco . . . would be paid by NCNB if Justin otherwise defaulted on the contract after the skins were sent."). See generally WUNNICKE ET AL., supra note $31, \S 2.04$.

As is true with commercial letters of credit, see supra note 22 , standby letters of credit can be "clean"-meaning that the beneficiary can demand payment without any accompanying documentation. See 1 Dolan, supra note 11, I 1.07[2], and cases cited therein.

51. See, e.g., P.A. Bergner, 140 F.3d at 1116 ("[O]n July 19, 1991, AMC submitted conforming documents [evidencing Bergner's default] and drew $\$ 31,207,000$ under the letter of credit."). 


\section{Revocable and Irrevocable Letters of Credit}

Letters of credit may be either revocable or irrevocable. 52 While the issuer of a revocable letter of credit may unilaterally amend or cancel the credit at any time prior to the beneficiary's presentation, ${ }^{53}$ once an issuer has established an irrevocable letter of credit, the issuer may not amend or cancel the credit without the beneficiary's consent. 54

Former Article 5 created no presumption one way or another as to a letter of credit's revocability. ${ }^{55}$ Thus, under former Article 5, "when a letter of credit ... fail[ed] to specifically state whether it [wa]s revocable or irrevocable, ... the question of revocability" was left to the court. ${ }^{56}$ That said, courts deciding the issue of revocability under former Article 5 seemed generally inclined to find a letter of credit that was facially silent

52. See generally 1 Dolan, supra note 11 , It 1.10.

53. See U.C.C. $\$ 5-106$ (b) (1995) (providing that a party's rights and responsibilities under an issued letter of credit cannot be amended or cancelled without her consent "except to the extent the letter of credit provides that it is revocable"); see, e.g., Beathard v. Chi. Football Club, Inc., 419 F. Supp. 1133, 1139 (N.D. Ill. 1976) (applying the pre-UCP500 presumption of revocability, see infra note 60 , to two letters of credit that did not state on their face whether they were revocable or irrevocable, and holding that the issuer was entitled to revoke them prior to presentation). See generally Leon, supra note 219 , at 445 46.

54. See U.C.C. $\$ 5-106$ (b) ("After a letter of credit is issued, rights and obligations of a beneficiary, applicant, confirmer, and issuer are not affected by an amendment or cancellation to which that person has not consented except to the extent the letter of credit provides ... that the issuer may amend or cancel the letter of credit without that consent."); see, e.g., Conoco, Inc. v. Norwest Bank Mason City, N.A., 767 F.2d 470, 471 (8th Cir. 1985) (holding that the issuer's revocation of a six-month letter of credit without the beneficiary's consent after only three months was wrongful, where the letter provided that it would "remain in force for a period of six (6) months from August 5, 1981, and w[ould] be available to [the beneficiary] on its sight draft for $100 \%$ invoice cost to be accompanied by a letter of demand from [the beneficiary] and supported by commercial invoices"); Braun v. Intercontinental Bank, 466 So. 2d 1130, 1132 (Fla. Dist. Ct. App. 1985) ("The irrevocable letter of credit was issued by Intercontinental for the benefit of Griferia. Although Intercontinental was on notice that Braun [the applicant] wished to cancel the letter of credit, this wish could not be carried out without the consent of Griferia."). See generally Leon, supra note 219 , at 446.

55. See U.C.C. $\S 5-103 \mathrm{cmt}$. 1 (1962) ("[T]he engagement may be either revocable or irrevocable ... . Neither the definition [of "letter of credit" in former section 5-103(1)(a)] nor any other section of this Article deals with the issue of when a credit, not clearly labelled as either revocable or irrevocable within the one or the other category."). See generally 1 Dolan, supra note 11, II 1.10 \& n.305 (also noting that two states-Florida and Louisiana-adopted non-uniform former Article 5 provisions creating a presumption of irrevocability).

See U.C.C. $\$ 5-115 \mathrm{cmt} .3$ (advising that, because "revocable credits may be modified or revoked without notice to the customer or the beneficiary, rights against the issuer like those here provided can hardly arise under them"). See generally 6B HawkLAND \& HOL. LAND, supra note 37, \$ 5-115:1.

56. 6B HawkLand \& Holland, supra note 37, § 5:103-2; see, e.g., Data Gen. Corp. v. Citizens Nat'l Bank of Fairfield, 502 F. Supp. 776, 783 (D. Conn. 1980) ("If the letter of credit is silent, the answer to whether it is irrevocable depends on case law."); W. Va. Hous. Dev. Fund v. Sroka, 415 F. Supp. 1107, 1111-13 (W.D. Pa. 1976) ("[T] he court receives only minimal guidance from Article Five of the Uniform Commercial Code in determining whether this letter of credit is revocable and must look to the facts and general law." (quotation omitted)). 
on the issue to be irrevocable. ${ }^{57}$ Although former Article 5 made no presumption as to revocability, it did condition the application of its anticipatory repudiation provision on the subject letter of credit being irrevocable..$^{58}$ Revised Article 5 explicitly states, "[a] letter of credit is revocable only if it so provides." ${ }^{59}$ The current UCP ${ }^{60}$ and the ISP98 ${ }^{61}$ both presume irrevocability.

\section{Anticipatory Repudiation: A Brief Review}

Suppose that on May 1, $A$ agrees to purchase an automobile from $B$, and $B$ agrees to sell it to $\mathrm{A}$ for $\$ 15,000$. $A$ and $B$ further agree that $A$ will pay $B$ the full $\$ 15,000$ purchase price on July 1 , at which time $B$ will transfer title to the automobile to $A$. While $A$ is not obligated to perform until July 1, his May 1 promise creates immediate duties: $A$ is required both to perform as promised on July 1 and to refrain from repudiating his promise to $B$ at any time prior to July 1 . If, at any time prior to July $1, A$ definitely and unconditionally manifests to $B$ his inability to, or his intent not to, perform as and when promised, then $A$ 's repudiation constitutes an anticipatory breach of the contract-despite the fact that $B$ has no right to expect $A$ to perform until July $1 .{ }^{62}$

57. See, e.g., Diskmakers, Inc., v. DeWitt Equip. Corp., 555 F.2d 1177, 1178 (3d Cir. 1977) ("[W]hen the contract spoke of a 'letter of credit' without designating it as revocable, the language must be construed as requiring an irrevocable instrument."); Data Gen. Corp., 502 F. Supp. at 783 ("A revocable letter of credit provides the beneficiary seller with little protection. Therefore, unless otherwise provided in the letter of credit itself, there should be a presumption in favor of irrevocability."). See generally 1 DOLAN, supra note 11 , If $4.06[2][\mathrm{a}]$.

58. See U.C.C. $\$ 5-115 \mathrm{cmt} .3$ (advising that, because "revocable credits may be modified or revoked without notice to the customer or the beneficiary, rights against the issuer like those here provided can hardly arise under them"). See generally 6B HaWKLAND \& Holland, supra note $37, \$ 5-115: 1$.

59. See U.C.C. \$ 5-106(a) (1995). See generally 1 DoLAN, supra note 11, Яl 4.06[2][a].

60. See UCP500, supra note 1, art. 6(c) (providing that, in the absence of a clear indication whether the letter of credit is revocable or irrevocable, the letter of credit "shall be deemed to be irrevocable"). Prior to 1993 , the UCP explicitly presumed revocability. See UCP400, supra note 37 , art. 7 (c) (providing that, in the absence of a clear indication whether the letter of credit is revocable or irrevocable, the letter of credit "shall be deemed to be revocable"); see, e.g., Conoco v. Norwest Bank Mason City, N.A., 767 F.2d 470, 470 (8th Cir. 1985) ("[A]bsent clear indication of irrevocability, such credits are deemed revocable."). See generally International Chamber of Commerce, Pub. No. 511, DocuMENTARY CREDITS: UCP 500 \& 400 COMPAREd 14 (Charles del Busto ed. 1993); 1 Dolan, supra note 11, II 4.06[2]; Ross P. Buckley, The 1993 Revision of the Uniform Customs and Practice for Documentary Credits, 28 GEO. WASH. J. INT'L L. \& ECON. 265, 295 (1993).

61. See ISP98, supra note 10, R. 1.06(a) ("A standby is an irrevocable, independent, documentary, and binding undertaking when issued and need not so state."). Official Comment 3 to Rule 1.06 further states that ISP98 makes "no provision" for revocable standby letters of credit and "offers no insight into the particular questions relevant to a revocable undertaking." BYRNE, supra note 41, at 25; see also ISP98, supra note 10, R. 7.01 ("A beneficiary's rights under a standby may not be cancelled without its consent.").

The United Nations Convention on Independent Guarantees and Stand-By Letters of Credit, likewise, presumes irrevocability. See U.N. Convention, supra note 34, art. 7(4) ("An undertaking is irrevocable upon issuance, unless it stipulates that it is revocable.").

62. See Rowley, supra note 31 , at 566 , and the cases cited therein. 
A promisor may repudiate either by word or by action. ${ }^{63}$ If a promisor tells his promisee that he either cannot, or will not, perform the contract as and when promised, the promisor's statement will generally operate as an anticipatory breach ${ }^{64}$ Likewise, a promisor may anticipatorily breach if he commits some voluntary act that makes it impossible for him to perform the contract when and as promised.65 Absent a contractual or legal duty to speak or act, ${ }^{66}$ a promisor generally cannot anticipatorily repudiate by mere silence or inaction. ${ }^{67}$

A promisee whose promisor has repudiated his obligation may: (1) do nothing, subject to the promisee's obligation to mitigate damages, ${ }^{68}$ and

63. See U.C.C. \& 2-610 cmt. 1 (1989) ("[A]nticipatory repudiation centers upon an overt communication of intention or an action which renders performance impossible or demonstrates a clear determination not to continue with performance.").

64. See id. \$ 2-610 \& cmt. 1; see, e.g., Cary Oil Co. v. MG Ref. \& Mktg., Inc., $90 \mathrm{~F}$. Supp. 2d 401, 411 (S.D.N.Y. 2000) (holding that the defendants anticipatorily repudiated their flexible delivery petroleum agreements with the plaintiffs when they wrote the plaintiffs purporting to "confirm" a non-existent "agreement" to cancel the contracts and "relieve both parties of any obligation thereunder"); P.R.S. Int'l, Inc. v. Shred Pax Corp., 703 N.E.2d 71, 80 (Ill. 1998) ("PRS ... indicated to Shred Pax that it would refuse to accept delivery of the pyrolysis system. In addition, PRS officers stated to Shred Pax that . . . PRS's owners were attempting to become 'completely disassociated with anything to do with tire shredding and/or burning.' Thus, PRS repudiated the contract with Shred Pax."); Trinidad Bean \& Elevator Co. v. Frosh, 494 N.W.2d 347, 354 (Neb. Ct. App. 1992) (holding that the defendant anticipatorily repudiated his contract to sell beans to the plaintiff when he walked into the plaintiff's offices and directed plaintiff's agent "to tear up the contract because [defendant] wanted no contract"); Tenavision, Inc. v. Neuman, 379 N.E.2d 1166, 1168 (N.Y. 1978) (holding that a purchaser of TV sets anticipatorily repudiated by communicating to its seller "that the sets were no longer needed and that delivery would not be accepted"); Am. Bronze Corp. v. Streamway Prods., 456 N.E.2d 1295, 1301 (Ohio Ct. App. 1982) ("American's Vice-President ... stated unequivocally on January 24, 1980 that American would not perform any further on the three contracts and in fact had melted down those units already produced. ... Therefore, American anticipatorily repudiated these contracts and became liable to Streamway.").

65. See, e.g., In re Okla. Trash Control, Inc., 258 B.R. 461, 465 (Bankr. N.D. Okla. 2001 ) (holding that the defendant anticipatorily repudiated when, after notifying the plaintiff that it had ceased operations and would no longer perform the terms of the contract, its sole employees moved out of the state); Champion v. Whaley, 311 S.E.2d 404, 407 (S.C. Ct. App. 1984) (holding that the defendants repudiated their contract to sell certain land to the plaintiffs because the defendants sold it to someone else).

66. See, e.g., Dade County v. Palmer \& Baker Eng'rs, Inc., 318 F.2d 18, 22 (5th Cir. 1963) (holding that county commission's failure to timely adopt certain resolutions that were essential to planning and funding a construction project was an anticipatory repudiation); Mid-State Homes, Inc. v. Brown, 256 So. 2d 894, 898 (Ala. Ct. App. 1971) (holding that seller anticipatorily repudiated land conveyance contract by permitting adjoining landowner to build a fence that encroached on the seller's land without objecting to the encroachment or notifying the purchaser of the encroachment prior to passage of title).

67. See, e.g., Sauer v. Xerox Corp., 938 F. Supp. 155, 165 (W.D.N.Y. 1996) (holding that a lessor could not infer from its lessee's failure to pay rent for a renewal period that the lessee would, likewise, fail to pay rent for a second renewal period and fail to pay the fair market value to purchase the leased goods at the end of the renewal term).

One notable instance in which silence or inaction will constitute a repudiation is if the silence or inaction is in response to a proper demand for adequate assurances of performance. See infra note 70.

68. See, e.g., In re St. Mary Hosp., 101 B.R. 451, 460 (Bankr. E.D. Pa. 1989) ("[T]he repudiatee has the burden of mitigating its damages by taking reasonable measures to minimize its losses."); Austin Hill Country Realty, Inc. v. Palisades Plaza, Inc., 948 S.W.2d 293, 
await the promisor's performance at the appointed time; 69 (2) seek assurances from the promisor that, his apparent repudiation notwithstanding, he will perform as and when promised; ${ }^{70}(3)$ cancel the contract; ${ }^{71}$ or (4) bring suit against the promisor or otherwise act in reliance on the repudiation. ${ }^{72}$ The promisee seeking assurances need only be reasonably uncertain that the promisor can perform, not absolutely certain that the promisor cannot perform. ${ }^{73}$ Nor, for that matter, does the promisee have

300 (Tex. 1997) ("A suit for anticipatory repudiation ... give[s] rise to the landlord's duty to mitigate damages upon the tenant's breach and abandonment.").

Article 5 imposes no such duty to mitigate on nonrepudiating beneficiaries. See infra notes 186-87 and accompanying text.

69. See U.C.C. \& 2-610(a) ("When either party repudiates the contract with respect to a performance not yet due the loss of which will substantially impair the value of the contract to the other, the aggrieved party may: (a) For a commercially reasonable time await performance by the repudiating party ...."); see, e.g., Fredonia Broad. Corp. v. RCA Corp., 481 F.2d 781, 801-02 (5th Cir. 1973) ("[T] he aggrieved party can refuse to accede to an anticipatory repudiation and can choose not to sue for the anticipatory repudiation. When the aggrieved party follows this course, the contract remains in existence."). But see, e.g., Cosden Oil \& Chem. Co. v. Karl O. Helm Aktiengesellschaft, 736 F.2d 1064, 1071-73 (5th Cir. 1984); Cargill, Inc. v. Stafford, 553 F.2d 1222, 1227 (10th Cir. 1977) (both suggesting that a buyer's ability to ignore a repudiation and await performance may be tempered by the buyer's duty to attempt cover within a reasonable time of learning of the repudiation, where the market price for the subject of the contract continues to rise from the date of repudiation through the date performance was due).

70. See U.C.C. $\$ 2-609$ (1) ("When reasonable grounds for insecurity arise with respect to the performance of either party the other may in writing demand adequate assurance of due performance and until he receives such assurance may if commercially reasonable suspend any performance for which he has not already received the agreed return."); see, e.g., Kaiser-Francis Oil Co. v. Producer's Gas Co., 870 F.2d 563, 568-69 (10th Cir. 1989) (holding that the plaintiff gas producer was entitled to seek adequate assurances from the defendant gas purchaser that it would perform under the take-or-pay contract between the parties after the defendant insisted that the plaintiff agree to an unfavorable amendment to the agreement as a precondition to the defendant's future performance).

71. See U.C.C. $\$ \S 2-610(b), 2-703(f), 2-711(1)$ (collectively recognizing a seller's and buyer's respective rights to cancel in response to a wrongful repudiation); see, e.g., Hudson Feather \& Down Prods., Inc. v. Lancer Clothing Corp., 513 N.Y.S.2d 173, 174 (N.Y. App. Div. 1987) (holding that a seller's refusal to respond to its buyer's demands for assurances "was a substantial impairment of the whole contract and the buyer was therefore entitled to cancel the contract and cease performance" (citation omitted)).

72. See U.C.C. $\$ \S 2-610(\mathrm{~b}), 2-703(\mathrm{c})-(\mathrm{e}), 2-711(1)-(2)$ (collectively recognizing a seller's and buyer's respective rights to immediately bring suit in response to a wrongful repudiation); see, e.g., In re Randall's Island Family Golf Ctrs., Inc., 261 B.R. 96, 103 (Bankr. S.D.N.Y. 2001) ("Gelman's attempt to withdraw his irrevocable offer prior to acceptance constituted an anticipatory repudiation. The debtors ... could immediately declare a breach and recover damages ...." (citations omitted)), aff'd, 272 B.R. 521 (S.D.N.Y. 2002); Trinidad Bean \& Elevator Co. v. Frosh, 494 N.W.2d 347, 351 (Neb. Ct. App. 1992) ("Section 2-610(b) provides a remedy for breach of contract before the time of performance has arrived. If a buyer chooses to treat the repudiation as a breach, . . . Section 2-711(1) provides that the buyer may cancel and recover any amount paid to the seller, as well as seek damages for cover or the contract-market differential." (citations omitted)); Wagal v. SI Diamond Tech., Inc., 998 S.W.2d 299, 300 (Tex. Ct. App.-Houston [1st Dist.] 1999, no pet.) (holding that "[w]hen a buyer repudiates a contract, the seller may resort to any remedy for breach provided by the UCC," including reclaiming the goods and suing the buyer for any difference between the contract price and the sum of the resale price and any payments made by the buyer).

73. See, e.g., Clem Perrin Marine Towing, Inc. v. Pan. Canal Co., 730 F.2d 186, 191 (5th Cir. 1984) (holding that "[i]t was certainly not unreasonable" for the defendant to "become alarmed" about the plaintiff's ability to perform after the defendant received a phone call 
to be correct about the promisor's apparent inability or unwillingness to perform, as long as the promisee's suspicion was reasonable. ${ }^{74}$ Once a party receives a "justifiable" written demand for adequate assurances, he must "provide within a reasonable time not exceeding thirty days such assurance of due performance as is adequate under the circumstances of the particular case."75 A promisor failing to timely provide adequate assurances has, as a matter of law, anticipatorily repudiated, entitling the party who sought assurances to immediately bring suit. ${ }^{76}$

A promisee who chooses to bring suit, to seek assurances, or to do nothing and await the promisor's performance, may urge the promisor to retract his repudiation and perform as and when promised. ${ }^{77}$ And, whether the promisee so urges, if the promisee has not cancelled the contract, materially changed her position, brought suit upon the repudiation, or otherwise indicated that she considers the repudiation to be final, the promisor may retract or otherwise cure his repudiation, ${ }^{78}$ foreclosing the

from a third party-who "had played a major role in brokering the deal between" the plaintiff and defendant "and could reasonably have been considered to have good information about [the plaintiff]'s financial status"-informing the defendant that the plaintiff was not current on financial obligations integral to the business relationship between the plaintiff and defendant).

74. See, e.g., Turntables, Inc v. Gestetner, 382 N.Y.S.2d 798, 799 (N.Y. App. Div. 1976) (holding that the defendant properly invoked section 2-609 "even though his suspicion that plaintiff was insolvent may have been inaccurate," as long as the defendant had "reasonable grounds for insecurity determined according to commercial standards, and of course good faith" (quotations and citation omitted)).

75. U.C.C. \& 2-609(4).

76. See id.; see, e.g., Land O'Lakes, Inc. v. Hanig, 610 N.W.2d 518, 523-24 (Iowa 2000) (finding that the defendant failed to satisfy section 2-609 when, inter alia, the defendant "assured" the plaintiff that he would perform only on a condition that could not be satisfied within thirty days of the plaintiff's justified demand for adequate assurances). See generally Rowley, supra note 31, at 619-20.

77. See U.C.C. $\S 2-610$ (b) ("When either party repudiates the contract with respect to a performance not yet due the loss of which will substantially impair the value of the contract to the other, the aggrieved party may ... (b) resort to any remedy for breach, even though he has notified the repudiating party that he would await the latter's performance and has urged retraction." (emphasis added)); Randall's Island Family Golf Ctrs., 261 B.R. at 101-02 ("[A]n anticipatory breach, like any other breach, gives the non-breaching party two mutually exclusive options. He may elect to treat the contract as terminated and exercise his remedies, or continue to treat the contract as valid. . . . He may refuse, for a time, to acquiesce in the repudiation, and urge the repudiator to perform without waiving any of his rights." (citations omitted)); see, e.g., Mobil Oil Exploration \& Producing S.E., Inc. v. United States, 530 U.S. 604, 621-22 (2000) ("The Government . . . cannot claim that the companies waived their rights simply by urging performance. Nor has the Government convinced us that the companies' continued actions under the contracts amount to anything more than this urging of performance." (citations omitted)); Mindel v. Image Point Prod., Inc., 725 F. Supp. 189, 194 (S.D.N.Y. 1989) ("Th[e] effect of Mindel's repudiation was not altered by Image Point's attempts to convince Mindel to change his mind . . .."); Jon-T Farms, Inc. v. Goodpasture, Inc., 554 S.W.2d 743, 746-47 (Tex. Civ. App.-Amarillo 1977, writ ref'd n.r.e.) ("After receiving Jon-T's December 10 letter of repudiation, Goodpasture refused to honor Jon-T's drafts. Such a suspension of performance is authorized specifically by [section 2-610(b)] . . . Goodpasture also demanded that Jon-T honor the contract. This, too, is authorized by [section 2-610(b)].").

78. See U.C.C. $\$ 2-611$ (1) ("Until the repudiating party's next performance is due he can retract his repudiation unless the aggrieved party has since the repudiation cancelled or materially changed his position or otherwise indicated that he considers the repudiation final."). Compare, e.g., Truman L. Flatt \& Sons Co. v. Schupf, 649 N.E.2d 990, 996 (Ill. 
promisee's ability to prevail on a claim for damages based on the promisor's anticipatory breach. In any event, the promisor's repudiation relieves the promisee from any further tender or performance that would otherwise be due under the contract. ${ }^{79}$

Not all repudiations give rise to an immediate cause of action. Courts generally refuse to apply the doctrine of anticipatory repudiation to unilateral contracts, including unilateral contracts to pay money. ${ }^{80}$ Likewise, courts generally hold that, once one party to a bilateral contract has fully performed, any repudiation by the party who has yet to perform will generally not support a claim of anticipatory breach. ${ }^{81}$ On the other hand, if

App. Ct. 1995) ("[D]efendants admitted ... they had not entered another agreement to sell the property, nor even discussed or considered the matter with another party. Defendants had not changed their position at all, nor do defendants make any attempt to so argue."), with, e.g., Neptune Research \& Dev., Inc. v. Teknics Indus. Sys., Inc., 563 A.2d 465, 472 (N.J. Super. Ct. App. Div. 1989) (holding that the repudiator's attempted retraction was foreclosed by the nonrepudiating party's prior cancellation of the contract), and Lake Erie Distribs., Inc. v. Martlet Importing Co., 634 N.Y.S.2d 599, 601 (N.Y. App. Div. 1995) (holding that a franchisor's attempt to retract its repudiation of its franchise agreement was ineffective, because the franchisee had already filed suit before the franchisor retracted).

A repudiating party may retract "by any method which clearly indicates to the aggrieved party that the repudiating party intends to perform." U.C.C. $\$ 2-611(2)$. Compare, e.g., A1 Ferro Commodities Corp., S.A. v. Tube City Iron \& Metal Co., 728 F. Supp. 1158, 1164 (E.D. Pa.) ("Tube City proposed to A1 Ferro to take delivery of the scrap shortly after expiration of the December 4, 1987 deadline. In a telex dated December 8, 1987, Tube City stated that it could have a ship ready during the December 10-20, 1987 period. A1 Ferro ... . sent a telex to Tube City on December 8, 1987, agreeing to extend the shipment delivery date to December $10-20,1987$. The Court finds that, by telex dated December 8 , 1987, Tube City retracted its repudiation of the Agreement by clearly indicating to A1 Ferro its intent to perform under the Agreement."), aff'd, 914 F.2d 241 (3d Cir. 1990), with, e.g., Randall's Island Family Golf Ctrs., 261 B.R. at 102 ("[Frank] conceded that he never told Rich that Gelman would perform, saying that Gelman was awaiting confirmation that he was the Successful Bidder 'because it would only be at that time that Gelman would have to do anything.' . . . [T] hese equivocal statements did not convey Gelman's unconditional intention to honor his bid, and were not sufficient to retract his earlier repudiation.").

79. See U.C.C. \& 2-610(c); see, e.g., P.R.S. Int'l, Inc. v. Shred Pax Corp., 703 N.E.2d 71, 80 (Ill. 1998) ("PRS repudiated the contract with Shred Pax. . . . PRS's claim that Shred Pax breached the contract by failing to deliver the pyrolysis machine must fail; the duty to deliver was excused by PRS's own repudiation of the contract ...."); Great W. Sugar Co. v. World's Finest Chocolate, Inc., 523 N.E.2d 1149, 1155 (Ill. App. Ct. 1988) ("World's Finest repudiated the contract by refusing to accept the sugar which it contracted to purchase. Therefore, even if Great Western had not made a formal tender of the sugar a formal tender was excused by World's Finest's repudiation and did not constitute a condition precedent to World's Finest's duty to accept the sugar."); Hudson Feather \& Down Prods., Inc. v. Lancer Clothing Corp., 513 N.Y.S.2d 173, 174 (N.Y. App. Div. 1987) ("[S]eller, by its actions in a meeting between the parties in early May 1980, repudiated the whole contract, which repudiation permitted the buyer to suspend perfor mance ...." (citations omitted)).

80. See, e.g., Cobb v. Pac. Mut. Life Ins. Co., 51 P.2d 84, 88 (Cal. 1935) ("There can be no anticipatory breach of a unilateral contract."); Harris v. Time, Inc., 237 Cal. Rptr. 584, 588 (Cal. Ct. App. 1987) ("[T]he doctrine of anticipatory breach-by which an anticipatory repudiation will support an action for breach of contract without further performance by the plaintiff-is not applicable to unilateral contracts. The rationale is that the aggrieved party has already fully performed and would not be harmed by awaiting counterperformance at the time promised." (citations omitted)).

81. See, e.g., Minor v. Minor, 7 Cal. Rptr. 455, 457 (Cal. Ct. App. 1960) ("Since the bilateral contract had been fully performed by the wife, it congealed, so far as the husband 
the non-repudiating promisee has not yet fully performed, she can immediately sue the repudiating promisor, even though the latter's only contractual obligation is to pay the promisee money in exchange for her asyet-incomplete performance. ${ }^{82}$ A number of leading commentators-including both Professor Corbin ${ }^{83}$ and Professor Williston, ${ }^{84}$ who otherwise disagreed on the advisability of permitting a promisee to sue for anticipatory breach prior to the time the promisor's performance was due-and a slowly growing number of courts have questioned the logic behind excluding unilateral contracts (and bilateral contracts made unilateral by virtue of one party's performance) from the doctrine's reach. ${ }^{85}$ Thus far, however, theirs is not the prevailing view.

was concerned, into a unilateral contract.... [T] he trial court's ruling that the doctrine of anticipatory breach does not apply to a contract which has become unilateral because of the opposite party's full performance finds uncontradicted support in California law."); Long Island R.R. v. Northville Indus. Corp., 362 N.E.2d 558, 563 (N.Y. 1977) ("The doctrine of anticipatory breach has not generally been applied to all types of contracts, its application being limited ordinarily to bilateral contracts embodying some mutual and interdependent conditions and obligations.... For the doctrine to apply there must be 'some dependency of performances.' For this reason, a party who has fully performed cannot invoke the doctrine even though the other party has repudiated." (citation omitted)) Sethre v. Wash. Educ. Ass'n, 591 P.2d 838, 843 (Wash. Ct. App. 1979) ("The doctrine of anticipatory breach of contract does not apply because Sethre and the others, by working for the Association over a period of years, had fulfilled all of their obligations under the pension agreements. An anticipatory breach cannot occur where one party has performed all of his duties under the contract.").

82. See, e.g., Equitable Trust Co. of N.Y. v. W. Pac. Ry., 244 F. 485, 501 (S.D.N.Y. 1917) ("[I]f performance remains mutually executory, the doctrine still applies, even though the promise is only to pay money, because that is the situation in the ordinary contract of sale repudiated by the buyer."), aff'd, 250 F. 327 (2d Cir. 1918).

83. Professor Corbin argued that the exclusion of unilateral contracts is based upon the erroneous idea that the reason for holding an anticipatory repudiation to be a breach of contract is that otherwise the injured party must himself continue to be ready to perform on his own part. It would follow from this that, if the injured party never had any performance to render on his part, or, having such a performance, has already fully performed it, it would not be necessary for his protection to give him an immediate action for damages for the anticipatory breach. ... [T] he rule allowing an action for an anticipatory breach cannot properly be rested upon this reason. The reasons upon which it can actually be sustained are equally applicable to unilateral contracts. The harm caused to the plaintiff is equally great in either case; and it seems strange to deny to a plaintiff a remedy of this kind merely on the ground that he has already fully performed as his contract has required.

4 Arthur L. Corbin, Corbin on Contracts 864-65 (1951) (footnote omitted).

84. Professor Williston wrote that the reasons supporting the doctrine of anticipatory repudiation are

as applicable to unilateral obligations to pay money, for instance by promissory note, as to any other form of contract. Indeed, the right to the unimpeached efficacy of the obligation before its maturity is perhaps as desirable in the case of a promissory note as in any other case which can be put; ... nor is it easy to draw a distinction between unilateral promises to pay money and unilateral promises for other performances.

Samuel Williston, The Law of Contracts 2381 (1920). Thus, if one were to concede the viability of a right to sue before the performance date, Williston saw no rational basis for limiting that right to mutually executory bilateral contracts.

85. See Rowley, supra note 31 , at 569-71, 604, and the sources cited therein. Judge Posner recently added his voice to the growing chorus: 
It is easy to imagine that the same courts which refuse to afford a claim for anticipatory repudiation to a promisee whose promisor's sole (remaining) promise is to pay money would, likewise, refuse to afford a claim for anticipatory repudiation to a letter of credit beneficiary whose issuer's sole promise is to pay money. And yet, reality is not always as we imagine it.

\section{ANTICIPATORY REPUDIATION OF LETTERS OF CREDIT}

Now, suppose that, before agreeing to sell an automobile to $A$ for $\$ 15,000, B$ insists that $A$ obtain an irrevocable letter of credit in $B$ 's favor to insure $A$ 's promise to pay $B$ the purchase price on July 1 . Suppose, further, that $A$ arranges to have Issuing National Bank ("INB") issue an irrevocable standby letter of credit in $B$ 's favor in the amount of $\$ 15,000$, payable at any time within thirty days after July 1 , upon $B$ 's presentation of the certificate of title to the automobile and a sworn affidavit evidencing $A$ 's failure to pay $B$ as promised. While $I N B$ is not obligated to honor the letter of credit until at least July 2, and then only if $A$ defaults on his payment obligation to $B$, must $I N B$ (as was true for $A$ in the earlier hypothetical) refrain from repudiating, at any time prior to $B$ 's presentation, its promise to honor $B$ 's conforming presentation?

Why the doctrine of anticipatory repudiation should be so limited eludes our understanding. Announcement by the other party that he has no intention of paying should entitle the prospective victim of the payor's breach to take immediate steps to protect his interest, as by suing. Against this it has been argued that the doctrine of anticipatory repudiation "will not intercede to rescue the promisee from the consequences of the absence of an acceleration clause." That gets it backwards. . . . Acceleration clauses are a standard contract provision for protecting the payee against the consequences of a breach by the other party; they would be unnecessary were it not for the rule carving out the completed-performance case from the operation of the doctrine of anticipatory repudiation.

Cent. States, S.E. \& S.W. Areas Pension Fund v. Basic Am. Indus., Inc., 252 F.3d 911, 91516 (7th Cir. 2001) (quoting Rosenfeld v. City Paper Co., 527 So. 2d 704, 706 (Ala. 1988)) (citations omitted). 


\section{Article 5 of the Uniform Commercial Code $^{86}$ and common law ${ }^{87}$ both}

86. See U.C.C. $\$ 5-111$ (a) (1995) ("If an issuer . . repudiates its obligation to pay money under a letter of credit before presentation, the beneficiary, successor, or nominated person ... may recover from the issuer the amount that is the subject of the ... repudiation."); U.C.C. $\$ 5-115(2)$ (1962) ("When an issuer wrongfully cancels or otherwise repudiates a credit before presentment of a draft or demand for payment drawn under it the beneficiary has the rights of a seller after anticipatory repudiation by the buyer under $\$ 2-610 \ldots . .$.$) .$

Each state (and the District of Columbia) has a corresponding statutory provision. AlA. Code \$ 7-5-111(a) (1997); Alaska Stat. \$ 45.05.111(a) (Michie 2001); Ariz. Rev. Stat. Ann. \$ 47-5111(A) (West 1997); Ark. Code Ann. \$ 4-5-111(a) (Michie 2001); CAl. Com. Code $\S 5111$ (a) (West 2002); Colo. Rev. Stat. Ann. § 4-5-111(a) (West 2001); Conn. Gen. Stat. Ann. \$ 42a-5-111(a) (West Supp. 2002); Del. Code Ann. tit. 6, \$ 5-111(a) (1999); D.C. Code Ann. \$ 28:5-111(a) (2001); Fla. Stat. Ann. § 675.111(1) (West Supp. 2002); Ga. Code AnN. § 11-5-111(a) (Supp. 2002); Haw. Rev. STAt. § 490:5-111(a) (1999); Idaho Code $\S 28-5-111$ (1) (Michie 2001); Ill. Comp. Stat. AnN. ch. 810, 9ा 5/5-111(a) (West Supp. 2002); Ind. CodE ANN. \& 26-1-5.1-111(a) (Michie Supp. 2002); Iowa CodE AnN. § 554.5111(1) (West 2001); Kan. Stat. AnN. \$ 84-5-111(a) (1996); Ky. Rev. Stat. AnN. § 355.5-111(1) (Michie 2002); LA. Rev. Stat. AnN. \& 10:5-111(a) (West 2001); Me. Rev. Stat. Ann. tit. 11, \& 5-1111(1) (West Supp. 2001); Md. Code Ann., Com. Law I § 5 111(a) (2002); Mass. Gen. Laws AnN. ch. 106, $\$$ 5-111(a) (West 1999); Mich. Comp. Laws AnN. \$ 440.5111(1) (West Supp. 2002); Minn. STAT. AnN. \& 336.5-111(a) (West 2002); Miss. Code Ann. § 75-5-111(a) (West 1999); Mo. AnN. Stat. § 400.5-111(a) (Vernon Supp. 2002); Mont. Code Ann. § 30-5-131(1) (2001); Neb. Rev. Stat. U.C.C. \$ 5-111(a) (Lexis 2000); Nev. Rev. Stat. AnN. $\$ 104.5111 .1$ (Michie 2000); N.H. Rev. Stat. AnN. § 382-A:5-111(a) (2002); N.J. STAT. AnN. § 12A:5-111(a) (West Supp. 2002); N.M. Stat. ANN. § 55-5-111(a) (Michie Supp. 2001); N.Y. U.C.C. § 5-111(a) (McKinney 2001); N.C. Gen. Stat. \$ 25-5-111(a) (2001); N.D. Cent. Code \& 41-05-11(1) (1999); Ohio Rev. Code Ann. § 1305.10(A) (West Supp. 2001); Okla. Stat. Ann. tit. 12A, \$ 5-111(a) (West 1998); Or. Rev. Stat. \$ 75.1110(1) (1999); 13 PA. Cons. Stat. Ann. \$ 5111(a) (West Supp. 2002); R.I. Gen. Laws § 6A-5-111(a) (2001); S.C. Code AnN. § 36-5-111(a) (Law. Co-op. 1976 \& Supp. 2001); S.D. CodIfied Laws \$ 57A-5-111(a) (Michie 2002); TENN. Code Ann. \$ 47-5-111(a) (2001); Tex. Bus. \& Com. Code AnN. \$ 5.111(a) (Vernon 2002); Utah Code Ann. § 70A-5-111(1) (2001); VT. Stat. Ann. tit. 9A, § 5-111(a) (2001); VA. Code Ann. \$ 8.5A-111(a) (Michie 2001); Wash. Rev. Code AnN. § 62A.5-111(1) (West Supp. 2002); W. VA. Code $\S 46-5-111$ (a) (2001); Wis. Stat. AnN. $\$ 405.115(1)$ (West 1995); Wyo. Stat. AnN. \$ 34.1-5-111(a) (Michie 2001).

87. See, e.g., Décor by Nikkei Int'l, Inc. v. Fed. Republic of Nigeria, 497 F. Supp. 893 , 906 (S.D.N.Y. 1980), aff'd, 647 F.2d 300 (2d Cir. 1981); J. Zeevi \& Sons, Ltd. v. Grindlays Bank (Uganda) Ltd., 333 N.E.2d 168, 172 (N.Y. 1975); Ross Bicycles, Inc. v. Citibank, N.A., 606 N.Y.S.2d 192, 193 (N.Y. App. Div. 1994) (all finding a cause of action for anticipatory repudiation of a letter of credit in New York common law).

Common-law recognition was very important in New York, prior to its adoption of Revised Article 5 in 2000, because New York's version of former Article 5 contained a nonuniform provision to the effect that, if the parties to a letter of credit expressly or impliedly agreed that the letter of credit would be governed by the applicable UCP, see supra note 37, then Article 5 did not apply to the letter of credit. See N.Y. U.C.C. $\$ 5-102(4)$ (McKinney 1993) ("Unless otherwise agreed, this Article 5 does not apply to a letter of credit ... if by its terms or by agreement, course of dealings or usage of trade such letter of credit ... is subject in whole or in part to the Uniform Customs and Practice for Commercial Documentary Credits . . . ."); see, e.g., Décor by Nikkei, 497 F. Supp. at 907 ("[S]ince the letters of credit issued by $\mathrm{CBN}$ in favor of Nikkei and East Europe expressly state that the UCP was to govern the terms thereof, Article 5 of the New York U.C.C. and the remedies contained therein do not apply to these actions."). Because the UCP were-and remain-silent on the issue of anticipatory repudiation, see Engel Indus., Inc. v. First Am. Bank, N.A., 798 F. Supp. 9, 13 (D.D.C. 1992), New York courts looked to pre-Code New York common law to decide claims of anticipatory repudiation of a letter of credit prior to New York's adoption of Revised Article 5. See, e.g., De Smeth v. Bank of N.Y., 879 F. Supp. 13, 15 n.1 (S.D.N.Y. 1995 ) ("Defendant maintains that plaintiff cannot bring an action for anticipatory repudiation of the letter of credit . . . since the UCP provides an exclusive remedy for plaintiff. 
recognize that the issuer of an irrevocable 88 letter of credit is capable of anticipatorily repudiating its payment obligation to the beneficiary of the

This argument is rejected. Since the UCP is silent on the issue of anticipatory repudiation, I must look to New York state law to determine if plaintiff may recover damages. A claim for anticipatory repudiation is clearly permissible in letter of credit cases under New York law ...." (citations omitted)); Décor by Nikkei, 497 F. Supp. at 906-07 (finding that, because "[t]he UCP is silent, however, as to the remedies available to a beneficiary of a letter of credit where there has been a unilateral amendment of an irrevocable letter of credit by the issuer," the beneficiaries could "seek relief for the anticipatory repudiation of the credits under applicable pre-Code state law"). See generally Chantayan, supra note 33, at 20406.

The volume and consistency of cases finding a cause of action for anticipatory repudiation of a letter of credit in New York common law is remarkable, given the widespread refusal to recognize a comparable cause of action for anticipatory repudiation of other unilateral or unilaterally executory obligations. See supra note 80 and accompanying text.

Alabama, Arizona, and Missouri added similar non-uniform provisions to their enactments of former Article 5. See Ala. Code \& 7-5-102(4) (1975); Ariz. Rev. Stat. AnN. $\S 47-5102(D)$ (West 1988); Mo. Ann. Stat. $\S 400.5-102(4)$ (West 1994). There are no reported decisions indicating in what source of law Alabama, Arizona, or Missouri courts sought or would have sought refuge had an anticipatory repudiation case arisen under their non-uniform provisions. Indeed, there are no reported decisions applying Arizona's nonuniform section 47-5102(D) at all. And, in the handful of Alabama and Missouri cases invoking their former versions of non-uniform section 5-102(4), the Alabama and Missouri courts betrayed little inclination to stray from the UCP where the UCP appeared to speak to the issue before the court. See S. Energy Homes, Inc. v. AmSouth Bank of Ala., 709 So. 2d 1180, 1186 (Ala. 1998) (declining to read a "fraud exception" into the UCP that would allow the issuing bank to refuse to honor a conforming presentment if the issuing bank believed there was fraudulent information contained in the documents presented to the issuing bank); AmSouth Bank, N.A. v. Martin, 559 So. 2d 1058, 1063-64 (Ala. 1990) (same); Waidmann v. Mercantile Trust Co., N.A., 711 S.W.2d 907, 912-14 (Mo. Ct. App. 1986) (holding that issuing bank acted in accordance with the UCP's "strict compliance" standard when it refused to honor the beneficiary's draft, which was accompanied by nonconforming documents); see also Landmark Bank v. Nat'l Credit Union Admin., 748 F. Supp. 709, 714-15 (E.D. Mo. 1990) (citing Waidmann, 711 S.W.2d 907, in support of the proposition that Article 5 does not apply where the parties have incorporated the UCP into their letter of credit, unless the parties so provide, and finding that the issuer improperly dishonored a facially conforming draft by taking into account facts beyond the letter of credit and the documents submitted in support of the draft, in contravention of the UCP's version of the independence principle). But see Germania Bank v. Brehm, 763 F. Supp. 1030,1032 (E.D. Mo. 1991) (construing a provision in the letter of credit saying it was "to be governed and construed in accordance with Missouri law" to mean Missouri's Article 5; thus, essentially, trumping the effect of the letter's language expressly making it subject to the UCP).

Revised section 5-116(c), as adopted in Alabama, Arizona, Missouri, and New York, replaces former Ala. Code \$ 7-5-102(4), ARIz. Rev. Stat. AnN. § 47-5102(D), Mo. AnN. STAT. § 400.5-102(4), and N.Y. U.C.C. \& 5-102(4), and provides that the UCP "trump" Revised Article 5 only if the letter of credit expressly incorporates the UCP, and the UCP and Revised Article 5 conflict when applied to the letter of credit. Ala. CoDE \$ 7-5-116(c) (1997); Ariz. Rev. Stat. AnN. \& 47-5116(C) (West 1997); Mo. Ann. Stat. § 400.5-116(c) (West Supp. 2002); N.Y. U.C.C. $\$ 5-116$ (c) (McKinney 2001); see supra note 40 and accompanying text; see, e.g., ITM Enters., Inc. v. Bank of N.Y., 754 N.Y.S.2d 663, 664 (N.Y. App. Div. 2003) (clumsily observing that, where the parties have incorporated the UCP, but the UCP is silent, the court may "rely upon" Revised Article 5 "since it is not in conflict with the UCP"). Because the UCP is silent on the issue of anticipatory repudiation, section 5111(a) governs even if the parties have expressly agreed that their letter of credit is subject to the UCP.

88. As a practical matter, issuers can only anticipatorily repudiate irrevocable letters of credit, because "Ir] evocable letters of credit may be modified or revoked without notice to the ... beneficiary." 6B HawkLand \& MilleR, supra note 37, [Rev.] \& 5-111.1; see supra notes 52-61 and accompanying text. 
letter of credit before the latter presents a draft or demand for payment. $^{89}$ In this respect, letters of credit are unique among the payment devices and mechanisms governed by the Code. By comparison, Articles 3 (Negotiable Instruments) and 4 (Bank Deposits and Collections) are silent on the subject of anticipatory repudiation. ${ }^{90}$

89. An issuer may also repudiate its obligation to the applicant who induced it to issue the letter of credit. Revised section 5-111 does not explicitly grant the applicant a cause of action for anticipatory repudiation by the issuer, but one leading commentator argues that courts should see that as a "drafting error ... is not to be regarded as a prohibition of the omitted action, and therefore ... not displac[ing] the non-Code law under which the concept of liability for anticipatory repudiation of a contract has long been firmly established." 7a Lary Lawrence, Lawrence's Anderson on the Uniform Commercial Code $\S[$ Rev] 5-111:16 (3d ed. 2001) (footnotes omitted). For a discussion of the non-Article 5 law of anticipatory repudiation, see Rowley, supra note 31.

Because the UCP500, see supra notes 1,87, and the ISP98, see supra note 10, are both silent on the issue of anticipatory repudiation, unless the parties have expressly chosen the law of a jurisdiction that has not adopted Article 5, a court considering a claim or defense of anticipatory repudiation of a letter of credit should apply revised section 5-111, even if the parties have expressly incorporated the UCP or the ISP98. See generally Mid-Am. Tire, Inc. v. PTZ Trading Ltd., 768 N.E.2d 619, 636-37 (Ohio 2002) ("[W]hen a letter of credit expressly incorporates the terms of the UCP, but the UCP do[ ] not contain any rule covering the issue in controversy, the UCP will not [dis]place the relevant provisions of [Article 5].). The U.N. Convention, see supra note 34, is, likewise, silent on the topic of anticipatory repudiation.

90. See 6 William D. Hawkland \& Lary Lawrence, Uniform Commercial CODE SERIEs [Rev.] § 3-118:6 (1999) ("There is no doctrine of anticipatory repudiation on an instrument. Despite a maker's or acceptor's proclamation that he will not pay the instrument when due, the holder must wait until the day after maturity to commence an action."); see, e.g., Artistic Greetings, Inc. v. Sholom Greeting Card Co., 318 N.Y.S.2d 623, 625 (N.Y. App. Div. 1971) ("The time for payment is not accelerated, in the absence of an express provision to that effect, by the fact that the maker has declared his intention not to pay on the date when the instrument is due." (quotation omitted)). That said,

Payment is unlikely where the maker or acceptor has repudiated the obligation to pay the instrument .... Presentment in these situations would be an idle gesture. ... Rather than requiring the party to undergo the futile and time-consuming act of presentment, presentment is excused. Notice of dishonor is not excused because the indorser may be unaware of the . . . repudiation.

6 HaWKLAND \& LAWRENCE, supra, [Rev.] § 3-504:6 (footnotes omitted).

Article 3 does recognize the concept of "renunciation":

A person entitled to enforce an instrument, with or without consideration, may discharge the obligation of a party to pay the instrument (i) by an intentional voluntary act, such as surrender of the instrument to the party, destruction, mutilation, or cancellation of the instrument, cancellation or striking out of the party's signature, or the addition of words to the instrument indicating discharge, or (ii) by agreeing not to sue or otherwise renouncing rights against the party by a signed writing.

U.C.C. \& 3-604(a) (1990). This section replaced former section 3-605(1)(b), but its contours are unlike those of anticipatory repudiation under Articles 2, 2A, and 5. Under Article 3 , renunciation is an act by a person entitled to enforce an instrument that waives its rights against another party. See U.C.C. \$ 3-604(a). See generally LARY LAwrence, AN InTRODUCTION to PAymEnT Systems 125 (1997). The party whose rights are affected by the holder's renunciation is not injured by the renunciation, and thus has no need of an avenue to redress like that provided by sections 2-610, 2A-402, former 5-115(2), and revised 5-111(a) to parties who are injured by another's repudiation of, respectively, a goods sales contract, a goods lease contract, or a letter of credit.

Article 3 also recognizes a holder's right to accelerate the payment due date of an instrument otherwise payable at a definite time, see U.C.C. $\$ 3-108(\mathrm{~b})$ (ii) ("A promise or order is 'payable at a definite time' if it is payable on elapse of a definite period of time after sight 
or acceptance or at a fixed date or dates or at a time or times readily ascertainable at the time the promise or order is issued, subject to rights of ... (ii) acceleration ...."), or to demand additional collateral, see id. \$3-104(a)(3)(i) ("'[N]egotiable instrument' means an unconditional promise or order to pay a fixed amount of money, with or without interest or other charges described in the promise or order, if it: ... . (3) Does not state any other undertaking or instruction by the person promising or ordering payment to do any act in addition to the payment of money, but the promise or order may contain (i) an undertaking or power to give, maintain, or protect collateral to secure payment ...."), if the holder "deems himself insecure," or otherwise "in good faith believes that the prospect of payment . . . is impaired," U.C.C. $\$ 1-208$ (1999); see, e.g., Karner v. Willis, 710 P.2d 21, 22 (Kan. 1985) (affirming the trial and appellate courts' judgments that a bank, whose note with the debtor contained a provision which permitted the bank to accelerate the maturity of the debt if the bank deemed itself insecure, "acted in good faith in accelerating the debt and in setting off the note against the debtor's bank account").

An instrument may require that the obligor furnish additional collateral. ... at the will of the holder or at the option of the holder whenever he feels insecure. ... [I]n the event of the obligor's failure to furnish the additional security [if requested], the holder may accelerate the balance of the principal due. If the right to require additional security is at the will of the holder or at the option of the holder whenever he deems himself insecure, the holder may not exercise the right unless he believes in good faith that the prospect of payment or performance is impaired.

6 Hawkland \& Lawrence, supra, [Rev.] \$ 3-104:12 (footnotes omitted). Numerous courts have similarly recognized an Article 9 secured creditor's right to accelerate a secured indebtedness or to demand additional collateral if the secured creditor, in good faith, deems himself insecure as to either the indebtedness or the collateral. See, e.g., Van Bibber v. Norris, 419 N.E.2d 115, 124 (Ind. 1981); Jack M. Finley, Inc. v. Longview Bank \& Trust Co., 705 S.W.2d 206, 209 (Tex. App.-Texarkana 1985, writ ref'd n.r.e.); Sturman v. First Nat'l Bank, 729 P.2d 667, 677 (Wyo. 1986). See generally Ben Franklin Fin. Corp. v. Davis, 589 N.E.2d 857, 860 (Ill. App. Ct. 1992) ("An insecurity clause is a clause often inserted in security agreements and promissory notes which provides that one party or his successor in interest may accelerate payment or performance or require collateral or additional collateral when he deems himself insecure."); W. Rodney Clement, Jr., Enforcing Security Interests in Personal Property in Mississippi, 67 Miss. L.J. 43, 56 (1997) ("[M]ost security agreements permit the secured party to declare a default and accelerate the indebtedness when the secured party deems itself insecure or its prospect of payment impaired.").

Whether the holder's good faith belief that the prospect of payment is impaired should be judged objectively or subjectively is the source of a sharp split of authority, though all courts agree that the holder must, at least, honestly believe that the prospect of payment is impaired. Compare, e.g., Sheppard Fed. Credit Union v. Palmer, 408 F.2d 1369, 1371 (5th Cir. 1969) (applying Texas law), Kupka v. Morey, 541 P.2d 740, 747 (Alaska 1975), Richards Eng'rs, Inc. v. Spanel, 745 P.2d 1031, 1033 (Colo. Ct. App. 1987), Universal C.I.T. Credit Corp. v. Shepler, 329 N.E.2d 620, 624 (Ind. Ct. App. 1975), and Black v. Peoples Bank \& Trust Co., 437 So. 2 d 26, 28-30 (Miss. 1983) (all requiring objective reasonableness), with, e.g., Watseka First Nat'l Bank v. Ruda, 552 N.E.2d 775, 779-81 (Ill. 1990), Quest v. Barnett Bank, 397 So. 2d 1020, 1021-22 (Fla. Dist. Ct. App. 1981), Ginn v. Citizens \& S. Nat'l Bank, 243 S.E.2d 528, 530 (Ga. Ct. App. 1978), Farmers Coop. Elevator, Inc. v. State Bank, 236 N.W.2d 674, 678 (Iowa 1975), Karner, 710 P.2d at 22, Fort Knox Nat'l Bank v. Gustafson, 385 S.W.2d 196, 200 (Ky. 1964), Rigby Corp. v. Boatmen's Bank \& Trust Co., 713 S.W.2d 517, 526-27 (Mo. Ct. App. 1986), Salsbery v. Ford Motor Credit Co., 635 P.2d 669, 672 (Or. Ct. App. 1981), and Van Horn v. Van De Wol, Inc., 497 P.2d 252, 254 (Wash. Ct. App. 1972) (all requiring only subjective reasonableness). Discussing that split in detail, much less attempting to resolve it, is beyond the scope of this article.

The holder of a negotiable instrument payable on demand (or payable at a fixed date or on demand) may demand payment at a date earlier than anticipated without even a good faith belief that the prospect of future payment is impaired. See U.C.C. $\$ 1-208 \mathrm{cmt}$.; see, e.g., Kham \& Nate's Shoes No. 2, Inc. v. First Bank of Whiting, 908 F.2d 1351, 1357-58 (7th Cir. 1990); Taggart \& Taggart Seed, Inc. v. First Tenn. Bank, N.A., 684 F. Supp. 230, 235-36 (E.D. Ark. 1988), aff'd, 881 F.2d 1080 (8th Cir. 1989); Dominion Bank, N.A. v. Moore, 688 F. Supp. 1084, 1086-87 (W.D. Va. 1988); Spencer Cos. v. Chase Manhattan Bank, N.A., 81 B.R. 194, 199 (D. Mass. 1987); Pavco Indus., Inc. v. First Nat'l Bank of Mobile, 534 So. 2d 
To succeed on a claim for anticipatory repudiation of a letter of credit, a beneficiary must prove ${ }^{91}$ that the issuer clearly and unconditionally demonstrated its intent not to perform or its inability to perform as and when promised. ${ }^{92}$ This is the same standard Article 2 applies to plaintiffs

572, 576-77 (Ala. 1988); Flagship Nat'l Bank v. Gray Distrib. Sys., Inc., 485 So. 2d 1336, 1340 (Fla. Dist. Ct. App. 1986); Fulton Nat'l Bank v. Willis Denney Ford, Inc., 269 S.E.2d 916, 918-19 (Ga. Ct. App. 1980); Christie v. First Am. Bank, 908 S.W.2d 679, 680 (Ky. Ct. App. 1995); Waller v. Md. Nat'l Bank, 620 A.2d 381, 390-91 (Md. Ct. Spec. App. 1993); Centerre Bank of Kansas City, N.A. v. Distribs., Inc., 705 S.W.2d 42, 46-48 (Mo. Ct. App. 1985); Solar Motors, Inc. v. First Nat'l Bank of Chadron, 545 N.W.2d 714, 719-20 (Neb. 1996); Simon v. N.H. Savs. Bank, 296 A.2d 913, 915 (N.H. 1972); Allied Sheet Metal Fabricators, Inc. v. Peoples Nat'l Bank of Wash., 518 P.2d 734, 738 (Wash. Ct. App. 1974) (all finding that a holder owes no duty of good faith in calling a demand note). But cf. Bank One Texas, N.A. v. Taylor, 970 F.2d 16, 31-32 (5th Cir. 1992) (applying Texas law and finding that a holder must act in good faith when accelerating a note containing both a monthly payment schedule and a payable-on-demand clause). See generally 5A RONALD A. Anderson, ANDerson on the Uniform Commercial Code \$ 3-108:3 (3d ed. 1994) ("The obligation of good faith does not apply to demand instruments."); 2 ThомAs D. Crandall et al., Uniform Commercial Code $\$ 14.13 .3$ (1993 \& Supp. 2002). Similarly, where the instrument authorizes acceleration upon the obligor's default, the Code does not require the accelerating holder to have a good faith belief that the prospect of future payment is impaired. See, e.g., Bowen v. Danna, 637 S.W.2d 560, 562 (Ark. 1982); Peoples Bank \& Trust Co. v. Cermack, 658 So. 2d 1352, 1357 (Miss. 1995), overruled on other grounds by Adams v. United States Homecrafters, Inc., 744 So. 2d 736 (Miss. 1999); Glenfed Fin. Corp. v. Penick Corp., 647 A.2d 852, 859 (N.J. Super. Ct. App. Div. 1994) (all holding that section 1-208 does not apply to a note that provides for acceleration upon default). See generally 5A ANDERSON, supra, § 3-109:34 ("When a note ... provides [that] the holder has the option of accelerating it upon default. ... there is no limitation that the acceleration must be in good faith." (footnotes omitted)).

This right to accelerate-at least to the extent that it is based on the holder's good faith insecurity-is somewhat akin to the right of a promisee under Article 2 or Article 2A to demand adequate assurances from its promisor if the promisee has "reasonable grounds for insecurity . . . with respect to the [promisor's] performance." U.C.C. \& 2-609(1) (1989); id. $\S 2 \mathrm{~A}-401(2)$. The obvious difference, of course, is that the Article 2 or $2 \mathrm{~A}$ promisor can satisfy its promisee's insecurity by providing adequate assurances within a reasonable time, not to exceed thirty days. By contrast, if a holder demands payment in full pursuant to an acceleration clause, Article 3 provides no statutory means for the obligor to "decelerate" or otherwise avoid making payment in full. See U.C.C. $\$ 3-304(b)(3)$ (1990) ("If a due date with respect to principal has been accelerated, the instrument becomes overdue on the day after the accelerated due date.").

91. The beneficiary alleging anticipatory repudiation bears the burden of proof. See, e.g., Occidental Fire \& Cas. Co. v. Cont'l Bank, N.A., 725 F. Supp. 383, 388 (N.D. Ill. 1989), aff'd, 918 F.2d 1312 (7th Cir. 1990); Colo. Nat'l Bank v. Bd. of Comm'rs, 634 P.2d 32, 41 n.3 (Colo. 1981) (en banc).

In Occidental Fire \& Casualty, the district court found that the beneficiary (Occidental) failed to prove, by a preponderance of the evidence, that the issuer (Continental) had reduced the face value of the letter of credit without Occidental's consent. Occidental Fire \& Cas. Co., 725 F. Supp. at 388-89. On appeal, the Seventh Circuit freely admitted that, had the burden of proof been on Continental, rather than Occidental, Continental likely could not have proved by a preponderance of the evidence that it had Occidental's consent to reduce the face value of the letter of credit. Occidental Fire \& Cas. Co., 918 F.2d at 1323.

92. See, e.g., De Smeth v. Bank of N.Y., 879 F. Supp. 13, 15 (S.D.N.Y. 1995) ("To succeed on a claim for anticipatory repudiation of a letter of credit, plaintiff must be able to show that defendant clearly demonstrated its intent not to continue with performance ...."); Colo. Nat'l Bank, 634 P.2d at 41 n.3 ("We cannot conclude ... that the Bank anticipatorily repudiated its obligation to honor drafts under letter of credit numbers 1156 and 1157. The Bank merely indicated that it should not be required to honor drafts unless the County had incurred or committed to incur expenses to complete the road improve- 
who allege that the defendant anticipatorily repudiated a contract for the sale of goods. ${ }^{93}$ Because Article 5 does not define "repudiation," 94 courts must look elsewhere for guidance on what types of words and actions constitute anticipatory repudiation. Section $2-610$ is a logical place to look, given that former section 5-115(2) gave the beneficiary whose issuer had repudiated or cancelled prior to presentment "the rights of a seller after anticipatory repudiation by the buyer under Section 2-610,"95 and that, at least in the context of a commercial letter of credit, the beneficiary is a seller of goods. ${ }^{96}$ While revised section 5-111(a) lacks the explicit reference to section 2-610, there is no reason to expect courts to change their practice of referring to section 2-610 and the body of case law that has developed around it to decide whether an issuer has anticipatorily repudiated. And, in any event, the vast majority of courts apply essentially the same standard to common law anticipatory repudiation claims. ${ }^{97}$

The beneficiary may also have to prove that she was ready, willing, and able to perform, or to tender performance as and when promised. This does not mean that the beneficiary must present a conforming draft or demand as a precondition for bringing suit over the issuer's anticipatory repudiation. ${ }^{98}$ Nor does it mean that the beneficiary must perform or tender performance of the underlying obligation if the issuer's repudiation has made it clear that any such performance or tender would not induce the issuer to perform under the letter of credit. ${ }^{99}$ Thus, in Engel Industries, Inc. v. First American Bank, N.A., ${ }^{100}$ the court made quick work of the repudiating issuer's argument that it was excused from per-

ments not that it would not honor the County's drafts unless this condition had been met.").

93. See supra note 63 .

94. See 2 Thomas M. Quinn, Quinn's Uniform Commercial Code Commentary \& LAW Digest \& 5-115[A][3] (2d ed. 2001).

95. U.C.C. \& 5-115(2) (1962).

96. See 7A LAWRENCE, supra note $89, \S 5-115: 6$ ("The refusal of the issuer to make payment under the [commercial letter of] credit is, for all practical purposes, the same as the buyer refusing to make payment. As a result, the damages that the beneficiary/seller will suffer by a[n issuer's repudiation] of a commercial letter of credit are the same as that of a seller of goods.").

97. See, e.g., Wolgin v. Atlas United Fin. Corp., 397 F. Supp. 1003, 1014 (E.D. Pa. 1975) ("An anticipatory breach of a contract occurs whenever there has been a definite and unconditional repudiation of a contract by one party communicated to another."), aff d, 530 F.2d 963 (3d Cir. 1976); Neptune Research \& Dev., Inc. v. Teknics Indus. Sys., Inc., 563 A.2d 465, 470 (N.J. Super. Ct. App. Div. 1989) ("An anticipatory breach is a definite and unconditional declaration by a party to an executory contract-through word or conduct-that he will not or cannot render the agreed upon performance.").

98. See U.C.C. $\S 5-111$ (a) (1995) ("In the case of repudiation the claimant need not present any document."); see also 1 DoLAN, supra note 11, II 9.02[2] (advising that a beneficiary need not make a conforming presentation "if the issuer indicates in advance that it will not honor a conforming presentation").

99. See, e.g., Ernesto Foglino \& Co. v. Webster, 216 N.Y.S. 225, 238 (N.Y. App. Div. 1926) (holding that the defendant's repudiation of the letter of credit relieved the plaintiff of any obligation to purchase the coal it had contracted to purchase from a third party and then resell to the defendant).

100. 798 F. Supp. 9 (D.D.C. 1992) (applying former Article 5). 
forming under the letter of credit because the beneficiary never made the requisite presentment:

First American repudiated the letter of credit before it expired, indicating to Engel that any presentation would be futile. Moreover, when Engel sought to preserve its rights and tried to perform its obligations under the letter of credit, First American prevented Engel from making presentation until the letter of credit expired. There is undisputed evidence that Engel was prepared to make presentation, that it had delivered the goods FOB its warehouse, and that presentation was not made only because First American's agent, the advising bank, would not accept presentment.

....

[B]eneficiaries of letters of credit cannot be allowed to collect without first meeting all of their obligations. . . . [B]ut to honor First American's defense would be to carry the concept of strict compliance to an extreme. In this case, Engel has complied with its obligations including the preparation of necessary documents .... First American cannot now prevail by claiming that Engel failed to do something First American specifically blocked Engel from doing. ....101

The issuer's repudiation notwithstanding, however, a beneficiary who could not have presented a conforming draft or demand may be unable to recover for the issuer's anticipatory repudiation. ${ }^{102}$ This is true even if

101. Id. at 14-15; see also, e.g., Procter \& Gamble Cellulose Co. v. Investbanka Beograd, 4 Fed. Appx. 49, 51 (2d Cir. 2001) ("[T]he formality of presenting the documents ... does not apply where, in instances such as this, the issuing bank anticipatorily repudiated the letters of credit, by indicating a clear intention not to perform its obligation, before the expiration of the period of presentment."), aff'g, No. 98 Civ. 2359 (JGK), 2000 U.S. Dist. LEXIS 5636, at *12 (S.D.N.Y. May 1, 2000) (finding no duty to tender further conforming drafts after the issuing bank refused to honor the beneficiary's first two conforming drafts); Clement v. FDIC, 2 UCC Rep. Serv. 2d 1017, 1023 (W.D. Okla. 1986) (finding no duty to tender documents under former $\$ 5-115(2)$ when presentment would be futile due to a prior renunciation by the issuer); Ross Bicycles, Inc. v. Citibank, N.A., 613 N.Y.S.2d 538, 539 (N.Y. Sup. Ct. 1994) ("[A]fter Citibank had dishonored th[e] four drafts requesting payment, plaintiff Ross Bicycles was not obliged to continue futilely presenting drafts and could recover for the anticipatory breach of the balance of the letter of credit.").

ISP98 may alter this rule with regard to standby letters of credit that are subject to ISP98-at least in cases like Procter \& Gamble Cellulose and Ross Bicycles where wrongful dishonor by the issuer of one or more conforming drafts was deemed a repudiation of the issuer's Article 5 obligation to honor future conforming drafts. See ISP98, supra note 10, R. 3.07(b) ("Wrongful dishonour of a complying presentation does not constitute dishonour of any other presentation under a standby or repudiation of the standby."). See generally WUNNICKE ET AL., supra note $31, \$ 6.04[\mathrm{~B}]$ (discussing R. 3.07(b) and concluding that its drafters appear to have intended to overturn the general rule that a beneficiary is not required to present documents if, prior to presentation, the issuer unambiguously repudiates its obligation to honor them). ISP98 rules only apply to letters of credit that specifically incorporate them by reference. See id. $\$ 6.01$.

102. See U.C.C. \& 5-111 cmt. 1 ("[I]f a beneficiary could never have obtained documents necessary for a presentation conforming to the letter of credit, the beneficiary cannot recover for anticipatory repudiation of the letter of credit."); see, e.g., Clement, 2 UCC Rep. Serv. 2d at 1023 (implying such a requirement in former section 5-115(2)); Décor by Nikkei Int'l, Inc. v. Fed. Republic of Nigeria, 497 F. Supp. 893, 907 (S.D.N.Y. 1980), aff'd, 647 F.2d 300 (2d Cir. 1981); Ufitec, S.A. v. Trade Bank \& Trust Co., 249 N.Y.S.2d 557, 560 (N.Y. App. Div. 1964), aff'd, 209 N.E.2d 551 (N.Y. 1965) (both finding such a requirement 
the issuer had previously accepted nonconforming documents ${ }^{103}$ or if routine practice permitted payment despite the nonconformity. ${ }^{104}$

\section{A. Repudiatory Words or Conduct}

What sort of behavior clearly and unconditionally demonstrates an issuer's intent not to perform, or its inability to perform, as and when promised? While the cases applying former section 5-115(2) or current section 5-111(a) are certainly not in legion, some patterns emerge.

\section{Cancellation or Renunciation}

As is true more generally under common law ${ }^{105}$ and under the more frequently litigated provisions of the Code dealing with anticipatory repu-

in pre-Code N.Y. law). But see Atari, Inc. v. Harris Trust \& Sav. Bank, 599 F. Supp. 592, 600 (N.D. Ill. 1984) (finding no requirement in former section 5-115(2) that a plaintiff demonstrate that, but for the defendant's repudiation, it was ready, willing, and able to make a conforming tender of documents), aff $d$ in part and rev'd in part, 785 F.2d 312 (7th Cir. 1986).

In Ross Bicycles, Inc. v. Citibank, N.A., 606 N.Y.S.2d 192, 193 (N.Y. App. Div. 1994), the Appellate Division stated that the plaintiff must show its readiness, willingness, and ability to perform, but cited as its sole authority a case-United Bank Ltd. v. Cambridge Sporting Goods Corp., 360 N.E.2d 943 (N.Y. 1976)-which nowhere discusses whether the plaintiff was ready, willing, and able to perform notwithstanding the defendant's repudiation. On remand, the trial court found that the "[p]laintiff clearly established that it could easily have ... satisf[ied] the terms of the letter of credit" - and was, therefore, entitled to recover the face value of the letter of credit where the defendant had repudiated before the plaintiff made any draws against the letter. See Ross Bicycles, 613 N.Y.S.2d at 539-40.

Former section 5-115 has no counterpart to the passage quoted above from Official Comment 1 to revised section 5-111. See U.C.C. § 5-115 cmts. 1-3 (1962). Despite this fact, and despite the conflicting authority cited above, Professors White and Summers appear to take it as given that "when beneficiary learns of the repudiation before procuring the required documents, it need not follow through with a complying presentation, but beneficiary must nevertheless show that it was 'ready, willing, and able' to do so. If beneficiary cannot show this, it will have no damage claim against issuer under 5-115." 3 JAMES J. White \& Robert S. Summers, Uniform Commercial Code: Practitioner Treatise SERIES 208 (4th ed. 1995) (emphasis added and footnote omitted). It is interesting to note that Professors White and Summers include Atari in the footnote wherein they cite the authorities purportedly supporting this obligation-despite the fact that the Atari court found no such obligation in former section 5-115(2). Id. Professors Crandall, Herbert, and Lawrence address the issue more circumspectly: "Some courts have added the requirement that the beneficiary show that she could have performed the contract in order to recover from an issuer that anticipatorily repudiated a credit." 3 CRANDALL ET AL., supra note 90, $\S 21.8 .3$.

103. De Smeth, 879 F. Supp. at 14-15.

104. Id. at 15 .

105. See, e.g., City of Fairfax v. Wash. Metro. Area Transit Auth., 582 F.2d 1321, 1325 (4th Cir. 1978) (" $\mathrm{II}] \mathrm{f}$ one party to a contract declares in advance that he will not perform at the time set for his performance, the other party may bring an immediate action for total breach of the contract."); Wolgin v. Atlas United Fin. Corp., 397 F. Supp. 1003, 1014 (E.D. Pa. 1975) ("A statement by a party that he will not or cannot perform in accordance with [the] agreement creates ... an anticipatory breach."), aff'd, 530 F.2d 963 (3rd Cir. 1976); Farwell Constr. Co. v. Ticktin, 376 N.E.2d 621, 627 (IIl. App. Ct. 1978) ("When a party to an executory contract gives notice of his intention not to comply with his obligations or otherwise repudiates his obligations before the time of performance, the other party may treat such notice as an anticipatory breach and regard the contract as terminated."). See generally RESTATEMENT (SECOND) OF CONTRACTS $§ 250 \mathrm{cmt}$. b, illus. 1 (1979). 
diation of contracts for the sale of goods, ${ }^{106}$ an issuer who cancels or otherwise renounces its obligations under a letter of credit anticipatorily repudiates the letter of credit. ${ }^{107}$

For example, in Atari, Inc. v. Harris Trust \& Savings Bank, ${ }^{108}$ Atari sold consumer electronics to S-W Distributors on an open account, secured by a $\$ 400,000$ irrevocable standby letter of credit issued by Harris on March 9, 1982 in Atari's favor. ${ }^{109}$ In order to draw against the letter of credit, Atari had to present documents stating, inter alia, that the amount Atari sought to draw was in excess of the $\$ 500,000$ open account Atari had established for S-W. ${ }^{110}$ On November 2, 1982, Harris unilaterally amended the letter of credit to raise the "floor" so that Atari could not draw against the letter in an amount less than $\$ 1,000,000.111$ While this act, by itself, was an anticipatory repudiation of the irrevocable letter of credit, ${ }^{112}$ the Atari court focused its analysis on a December 22, $1983^{113}$ letter from Harris notifying Atari that, as of December 10, 1983, the letter of credit "should be considered null and void."114 Atari informed Harris five days later that, because the letter of credit was irrevocable, Atari expected Harris to honor any proper demand for payment. On January 31 , 1984, Atari attempted to draw $\$ 395,391.68$, and submitted to Harris documentation including invoices totaling $\$ 2,120,679 .{ }^{115}$ Harris refused to honor Atari's draft due to alleged nonconformities in the documents

106. See supra note 64.

107. See, e.g., Procter \& Gamble Cellulose Co. v. Investbanka Beograd, No. 98 Civ. 2359 (JGK), 2000 U.S. Dist. LEXIS 5636, at *12 (S.D.N.Y. May 1, 2000) (holding that the issuing bank, which refused to honor two conforming drafts and then recalled the letters of credit from advising bank prior to their expiration, had anticipatorily repudiated because "it was clear that [the issuing bank] would not pay under the letters of credit"), aff'd, No. 00-7461, 2001 U.S. App. LEXIS 2434 (2d Cir. Feb. 15, 2001); Engel Indus., Inc. v. First Am. Bank, N.A., 798 F. Supp. 9, 11-13 (D.D.C. 1992) (holding that the issuing bank, which wrote beneficiary to inform it that the bank would not "mak[e] payment under" the letter of credit "at this time," had anticipatorily repudiated because, at the same time, the issuing bank wrote the advising bank that it would not pay under any circumstances); J. Zeevi \& Sons, Ltd. v. Grindlays Bank (Uganda) Ltd., 333 N.E.2d 168, 170-72 (N.Y. 1975) (holding that the issuing bank, which-on instructions from the Bank of Uganda-informed its New York agent to cancel the letter of credit and not to effect payment against it, "was guilty of an anticipatory breach of contract and became liable for damages caused the beneficiary" of the cancelled letter); see also Ernesto Foglino \& Co. v. Webster, 216 N.Y.S. 225, 238 (N.Y. App. Div. 1926) (holding, under pre-Code common law, that the defendant anticipatorily repudiated when it wrote the beneficiary some thirty days before the letter of credit should have expired that the credit had already expired). See generally 1 Dolan, supra note 11, I 9.02[2]; 7A LAWRENCE, supra note 89, \& 5-115:13.

108. 599 F. Supp. 592 (N.D. Ill. 1984), aff'd in part and rev'd in part, 785 F.2d 312 (7th Cir. 1986).

109. Id. at 594.

110. Id. at 595 .

111. Id.

112. See infra notes $142-59$ and accompanying text.

113. The court at one point refers to Harris having written this letter to Atari on December 27. Atari, $599 \mathrm{~F}$. Supp. at 595 . This appears to be a typographical error in the court's opinion, as everywhere else it indicates that Harris wrote the letter on December 22. Id. at 599,600 n. 4,601 .

114. Id. at 595 .

115. Id. 
Atari presented. ${ }^{116}$ Atari sued Harris for anticipatory repudiation.

While admitting that it had made an irrevocable promise to pay, ${ }^{117}$ Harris argued that: (1) the UCP, incorporated by the letter of credit, governed its transaction with Atari rather than former section 5-115(2); ${ }^{118}$ (2) Harris's December 22 letter did not amount to a repudiation;119 (3) Atari's reply to Harris's December 22 letter waived any repudiation by Harris; ${ }^{120}$ (4) Atari's January 31, 1984 draw waived any repudiation by Harris; ${ }^{121}$ and (5) Atari failed to show (or even allege) that it was ready, willing, and able to perform by presenting a conforming demand for payment under the letter of credit. ${ }^{122}$

The court found for Atari on all points. ${ }^{123}$ First, the court found that former section 5-115(2) applied, notwithstanding Harris's authority to the contrary, because Harris cited only New York cases applying a non-uniform statutory provision ${ }^{124}$ for which Illinois had no counterpart, and because prior Illinois cases had applied Article 5 even when the letter of credit explicitly incorporated the UCP. ${ }^{125}$ Second, the court found that

116. Id. Harris's refusal to honor Atari's draft, standing alone, might have supported a claim for wrongful dishonor under former section 5-115. U.C.C. \$ 5-115(1) (1962). However, while the extent and consequence of nonconformities in Atari's documents were hotly disputed by both parties, see Atari, 599 F. Supp. at 595-99, Harris did not dispute any of the facts supporting Atari's claim that Harris's December 1983 letter constituted an anticipatory repudiation (though it did dispute the legal consequence of those facts), id. at $599 \&$ n.2. Rather, Harris rested its defense of Atari's anticipatory repudiation claim on the bases discussed in the text accompanying infra notes 118-22.

117. Atari, 599 F. Supp. at 599.

118. Id.

119. Id. at 599 n.2.

120. Id. at 600 n. 4 .

121. Id. at 601 .

122. Id. at 600 .

123. The court, for its own purposes, also considered and rejected the argument that Harris had somehow retracted its prior repudiation when it considered, and then dishonored as nonconforming, Atari's January 31 draw.

If proper, Harris' dishonor of Atari's attempted draw, citing nonconformities with the terms of the credit, would amount to ... a retraction of its prior repudiation. ...

But Atari maintains that Harris' reliance upon the credit terms was merely a pretext. Atari contends that Harris' dishonor was actually based on Harris' position that the credit was no longer effective. Accepting Atari's argument necessarily leads to the conclusion that whenever an issuer has repudiated a letter of credit and its subsequent dishonor is ultimately determined to be wrongful by a court, the issuer is subject to liability under a theory of anticipatory breach as well as for the wrongful dishonor. Although this result provides a disappointed beneficiary with duplicate causes of action, this is exactly the result contemplated by the Official Comments to the UCC. . . Nor does this result do violence to those decisions requiring a beneficiary to meet the requirements of the credit should it attempt to draw on the credit after a repudiation. Only a wrongful dishonor, which necessarily includes a conforming draw, should be viewed as a continued repudiation. Should the issuer properly dishonor an attempted draw made subsequent to its repudiation, it has performed under the credit and retracted its repudiation.

Id. at 601 (footnote and citations omitted).

124. N.Y. U.C.C. $§ 5-102(4)$ (McKinney 1993), superseded by N.Y. U.C.C. $\S 5-116(c)$

(McKinney 2001) (effective Nov. 1, 2000); see supra note 87.

125. See Atari, 599 F. Supp. at 600. 
Harris's statement that Atari should consider the letter of credit "null and void" was "a clear statement by a promisor to its promisee that it will not perform"-and, therefore, it was a repudiation. ${ }^{126}$ Third, applying section 2-610 by analogy, ${ }_{127}$ the court held that Atari's reply to Harris's December 22 letter, demanding that Harris honor the letter of credit, did not waive Atari's right to sue Harris for anticipatory repudiation. ${ }^{128}$ Fourth, the court held that Atari's presentment on January 31, 1984 was "no more than a further urging that Harris retract its repudiation and perform" as promised-and, again, did not waive Atari's right to sue Harris for anticipatorily repudiating the letter of credit. ${ }^{129}$ And, fifth, the court, without conceding that former section 5-115(2) actually required a non-repudiating beneficiary to show that it was ready, willing, and able to perform in order to recover for an issuer's repudiation, ${ }^{130}$ held that Atari clearly was ready, willing, and able to perform, as evidenced by its January 31 presentation of conforming documents supporting a draw of $\$ 395,391.68$ against the letter of credit. ${ }^{131}$

In Colorado National Bank of Denver v. Board of Commissioners, ${ }^{132}$ CNB issued three irrevocable letters of credit in favor of Routt County to secure an obligation by Woodmoor to perform, or pay for, certain road improvements called for in a series of subdivision improvement agree-

126. Id. at 599 n.2.

127. Section 2-610, which governs anticipatory repudiation of contracts for the sale of goods, allows a non-repudiating party to, without waiving his right to immediately pursue any remedy afforded by section 2-610, "notif[y] the repudiating party that he would await the latter's performance and ... urge[] retraction." U.C.C. \& 2-610(b) (1989); see supra note 77. This is consistent with common law that developed following the adoption of the Code. See Restatement' (Second) of Contracts, supra note 105, \& 257 ("The injured party does not change the effect of a repudiation by urging the repudiator to perform in spite of his repudiation or to retract his repudiation."); see, e.g., Gaglia v. Kirchner, 721 A.2d 1028, 1031 (N.J. Super. Ct. App. Div. 1999) (observing that the non-breaching party "may choose to attempt to persuade the breaching party to retract his repudiation and to perform," but "is not required to do so").

128. See Atari, 599 F. Supp. at 600 n.4.

129. See id. at 601.

130. The court found, under Article Five of the UCC, it is not clear that Atari is required to show that it was ready, willing and able to perform. Section 5-115(2) expressly contemplates a situation where the beneficiary may sue the issuer for repudiation and still "avoid procurement of the required documents." In other words, there is no requirement that the beneficiary demonstrate that it could Id. at 600 . present a conforming draw.

The Atari court then cited two New York cases-Reprosystem, B.V. v. SCM Corp., 522 F. Supp. 1257 (S.D.N.Y. 1981), rev'd on other grounds, 727 F.2d 257 (2d Cir. 1983), and Décor by Nikkei International, Inc. v. Federal Republic of Nigeria, 497 F. Supp. 893 (S.D.N.Y. 1980), aff d, 647 F.2d 300 (2d Cir. 1981) - as contrary authority. However, as the Atari court had earlier observed, New York had at the time a non-uniform provision in its version of Article 5 stating that, where the parties expressly incorporated the UCP in their letter of credit, the UCP displaced former Article 5. Therefore, the New York cases cited by the Atari court did not find a "ready, willing, and able" requirement in Article 5, they found it in New York pre-Code common law. See supra note 87.

131. See Atari, 589 F. Supp. at 600.

132. 634 P.2d 32 (Colo. 1981) (en banc). 
ments. ${ }^{133}$ When Woodmoor failed to make any improvements, the county made a demand on CNB under the letter of credit. CNB dishonored all of the county's drafts, and the county sued for wrongful dishonor. ${ }^{134}$ The county also sued CNB on the theory of anticipatory repudiation, alleging that $\mathrm{CNB}$ had imposed a precondition-that the county have actually incurred, or committed to incur, any expenses for which it sought reimbursement before it could draw against the letters of credit-which was not part of the terms under which the letters were issued. ${ }^{135}$

In contrast to Atari's clear and unconditional "null and void" language, the only evidence the county presented at trial of CNB's repudiation was CNB's sworn answer to an interrogatory that, prior to the expiration date of the letters of credit, CNB had notified the county that CNB "should make payments under the letters of credit . . . only as the [county] incurred or committed to incur expenses for the particular improvements called for in the Subdivision Improvement Agreements."136 Far from being an "overt communication of intention or an action which renders performance impossible or demonstrates a clear determination not to continue with performance," 137 the Colorado Supreme Court found insufficient evidence of anticipatory repudiation in the foregoing statement:

We cannot conclude ... that the Bank anticipatorily repudiated its obligation to honor drafts under letter of credit numbers 1156 and 1157. The Bank merely indicated that it should not be required to honor drafts unless the County had incurred or committed to incur expenses to complete the road improvements not that it would not honor the County's drafts unless this condition had been met. ${ }^{138}$

While the court could have explained a bit more clearly why CNB's statement could not be a repudiation, it seems as if there are at least two possible "spins" to put on CNB's "should." CNB could have been saying "If life was fair, we should only have to pay you if you actually incurred or committed to incur the expenses; however, because the letters don't actually say that, we will honor any conforming drafts." Such a statement would clearly not be an anticipatory repudiation, because CNB did not say it could not or would not honor conforming drafts, it just said it did not want to. ${ }^{139}$ Alternatively, CNB could have been attempting to introduce a new term. As long as CNB did not insist on the new term and refuse to perform without it, ${ }^{140}$ merely proposing a new term is not an

133. Id. at 34 .

134. Id. at 34-35.

135. Id. at 41 n.3.

136. Id.

137. Id. (quoting Colo. Rev. Stat. $\$ 4-2-610 \mathrm{cmt} .1$ ) (1973)).

138. Id.

139. Cf. Barz v. Geneva Elevator Co., 12 F. Supp. 2d 943, 961 (N.D. Iowa 1998) (" $[\mathrm{P}]$ osturing over the legality of the contracts ... does not as a matter of law demonstrate a clear determination not to continue with performance, nor does it expressly renounce the contracts and announce an intention not to perform." (quotations omitted)).

140. See infra notes $142-43$. 
anticipatory repudiation. ${ }^{141}$

\section{Imposing or Insisting Upon New or Modified Terms}

As is also true more generally under common law, ${ }^{142}$ and under the more frequently litigated provisions of the Code dealing with anticipatory repudiation of contracts for the sale of goods, ${ }^{143}$ an issuer who unilaterally amends the terms of a letter of credit, or who insists, as a precondition to performance, on different terms than those set forth in the letter of credit, anticipatorily repudiates the letter of credit. ${ }^{144}$ This is consistent with former section 5-106(2) and revised section 5-106(b), both of which provide that post-issuance amendments of irrevocable letters of credit are ineffective unless and until consented to by all parties. ${ }^{145}$ It is also consistent with Article 9(d) of the UCP, which provides that, except in the case of a transferable credit (as defined by UCP Article 48(a)), an irrevocable letter of credit "can neither be amended nor cancelled without the agreement of the Issuing Bank, the Confirming Bank, if any, and

141. See, e.g., Unique Sys., Inc. v. Zotos Int'l, Inc., 622 F.2d 373, 377 (8th Cir. 1980) (“A suggestion for modification of a contract does not amount to a repudiation unless the party makes it clear that he will not perform without the modification."); Wooten v. DeMean, 788 S.W.2d 522, 526 (Mo. Ct. App. 1990) ("Mere requests to change the terms of a contract are not, in and of themselves, enough to constitute repudiation."); accord Truman L. Flatt \& Sons Co. v. Schupf, 649 N.E.2d 990, 994 (Ill. App. Ct. 1995) (following Unique Systems and Wooten).

142. See Restatement (Second) of Contracts, supra note $105, \$ 250 \mathrm{cmt}$. b ("L]anguage that under a fair reading 'amounts to a statement of intention not to perform except on conditions which go beyond the contract' constitutes a repudiation." (quoting U.C.C. \$ 2-610 cmt. 2 (1989)); see, e.g., REA Express, Inc. v. Interway Corp., 538 F.2d 953, 955 (2d Cir. 1976) ("[I]nsistence upon terms which are not contained in a contract constitutes an anticipatory repudiation thereof."); Beeson v. McDonald, 347 S.E.2d 485, 486-87 (N.C. Ct. App. 1986) ("When plaintiff tendered the agreed purchase price to defendants ... and coupled his tender with instructions to defendants that he would not 'close the transaction until the [d]efendants had agreed to said conditions' [not part of the parties' agreement], . . . the plaintiff repudiated the contract.").

143. See U.C.C. \$ $2-610 \mathrm{cmt} .2$ (1989) ("[A] demand by one or both parties for more than the contract calls for in the way of counter-performance is not in itself a repudiation .... However, when under a fair reading it amounts to a statement of intention not to perform except on conditions which go beyond the contract, it becomes a repudiation."); see, e.g., Unique Sys., 622 F.2d at 376 (holding that the defendant, Zotos, "unequivocally refused to perform" when its president "made it clear that Zotos would not . . . agree to purchase any systems until an extensive market test could be conducted in the field"-."a requirement found nowhere in the contract"); Aero Consulting Corp. v. Cessna Aircraft Co., 867 F. Supp. 1480, 1491 (D. Kan. 1994) ("A refusal to perform except upon conditions not required by the contract generally constitutes a repudiation.").

144. See, e.g., Décor by Nikkei Int'l, Inc. v. Fed. Republic of Nigeria, 497 F. Supp. 893, 899-900, 906 (S.D.N.Y. 1980), aff'd, 647 F.2d 300 (2d Cir. 1981); Nat'l Bank \& Trust Co. v. J.L.M. Int'l, Inc., 421 F. Supp. 1269, 1272 (S.D.N.Y. 1976). See generally 7A LAwRENCE, supra note 89 , at $\$$ 5-115:13; Leon, supra note 219 , at 447.

145. See U.C.C. $\$$ 5-106(b) (1995) ("After a letter of credit is issued, rights and obligations of a beneficiary, applicant, confirmer, and issuer are not affected by an amendment or cancellation to which that person has not consented except to the extent the letter of credit provides that it is revocable or that the issuer may amend or cancel the letter of credit without that consent."); U.C.C. \$ 5-106(2) (1962) ("Unless otherwise agreed once an irrevocable credit is established as regards the customer it can be modified or revoked only with the consent of the customer and once it is established as regards the beneficiary it can be modified or revoked only with the beneficiary's consent."). 
the Beneficiary."146

In National Bank \& Trust Co. v. J.L.M. International, Inc., ${ }^{147}$ the Federal Republic of Nigeria contracted, on March 1, 1975, to buy 240,000 metric tons of concrete from JLM for a total contract price of $\$ 14,400,000$, plus shipping and demurrage (delay) charges. ${ }^{148}$ Pursuant to the contract's terms, Nigeria, through the Central Bank of Nigeria, arranged in early April 1975 for Morgan Guaranty to open an irrevocable, transferable letter of credit in JLM's favor, and Morgan Guaranty notified JLM of the arrangement. ${ }^{149}$ On September 30, 1975, while the letter of credit remained in force, Morgan Guaranty notified JLM's assignee, Interexporte, that Nigeria had unilaterally amended the letter of credit to require prior approval for all demurrage charges. ${ }^{150}$ Prior to the September 30 amendment, Interexporte entered into a charter party agreement with Macia, whereby Macia agreed to provide transport for 180,000 metric tons of concrete, with an option for the other 60,000 tons. In order to secure the necessary vessels, Macia entered into a joint venture with Natbank to finance use of the vessels Macia needed to satisfy its contract with Interexporte. ${ }^{151}$ When Natbank learned of Nigeria's amendment, it sued. The court held, inter alia, that Nigeria's unilateral amendment to the letter of credit, imposed without JLM's or Interexporte's consent, anticipatorily repudiated the irrevocable letter of credit that Nigeria had induced Morgan Guaranty to issue in JLM's (and then, by assignment, Interexporte's) favor. ${ }^{152}$

In Savarin Corp. v. National Bank of Pakistan, ${ }^{153}$ Savarin agreed to sell 6,000 tons of wheat to Sharbatly-3,000 tons each to be delivered to Jeddah and Dammam, Saudi Arabia-pursuant to which Sharbatly arranged

146. UCP500, supra note 1, art. 9(d)(i); see Décor by Nikkei, 497 F. Supp. at 906 (relying on a comparable UCP400 provision).

147. 421 F. Supp. 1269 (S.D.N.Y. 1976).

148. Id. at 1270 .

149. Id.

150. Id. at 1271 .

Notwithstanding the court's recitation that "Morgan [Guaranty] posted notification to Interexporte that Nigeria had amended its letter of credit (\#CBN/BO/75/50) so as to impose the added requirement that demurrage payments would not be made unless the documents specified in the original credit were from that time on certified for payment by Central Bank" and that Nigeria's action "was apparently taken unilaterally without the consent of the other parties to the irrevocable letter of credit," $i d$. (emphasis added), it is not entirely clear how an applicant (Nigeria) can unilaterally amend the terms of a letter of credit between an issuer (Morgan Guaranty) and a beneficiary (JLM) or the beneficiary's assignee, Interexporte. The independence principle gainsays an applicant's ability to do so. Perhaps a better characterization of the facts of this case is that Nigeria "compelled" Morgan Guaranty to unilaterally amend its letter of credit without the prior consent of JLM's assignee, Interexporte.

151. Id.

152. Id. at 1272-73. Or, as discussed in supra note 150 , the decision might be better characterized as holding that Nigeria's insistence that Morgan Guaranty unilaterally amend the letter of credit, without JLM's or Interexporte's consent, anticipatorily repudiated the irrevocable letter of credit between Morgan Guaranty, as issuer, and Interexporte, as JLM's assignee.

153. 447 F.2d 727 (2d Cir. 1971). 
to have letters of credit issued in Savarin's favor by NBP.154 After receiving the letters of credit, Savarin wrote NBP on October 21, advising that Savarin wanted to ship all 3,000 tons bound for Dammam on a single vessel, rather than on three separate vessels as appeared to be called for in the letters of credit, ${ }^{155}$ and asked NBP to confirm that it would accept a draft supported by shipping documents from a single lot rather than three lots. ${ }^{156}$ On October 28, NBP indicated by cable that it would honor such a draft. ${ }^{157}$ Three days later NBP notified Savarin that it would only honor Savarin's draft if the shipment arrived on three separate ships. ${ }^{158}$ The Second Circuit held that NBP's October 31 refusal to honor any draft from Savarin that did not indicate shipment on three separate vessels was an anticipatory repudiation, because NBP had already agreed to amend the letter of credit to permit shipment on a single vessel. ${ }^{159}$

On the other hand, refusing to amend a letter of credit to conform to the desires of the parties to the underlying obligation, and then dishonoring drafts that do not conform to the unamended letter, is not an anticipatory repudiation of the letter of credit.

In B.E.I. International, Inc. v. Thai Military Bank, ${ }^{160} \mathrm{BEI}$ agreed to produce "hydra" rocket systems and sell them to the Royal Thai Army (RTA). To secure the RTA's obligation to pay the $\$ 2,370,084$ contract price, Thai Military Bank (TMB) issued an irrevocable letter of credit in BEI's favor. TMB also issued a "counterguarantee" in favor of RTA, in the amount of $\$ 237,008.40$, payable in the event that BEI failed to perform. BEI arranged for Worthen to issue an irrevocable standby letter of credit in the same amount in favor of TMB. ${ }^{161}$ Before Worthen's letter of credit expired on November 23, 1988, Worthen agreed to extend its effective date until April 23, 1989, due to delays BEI was experiencing in obtaining the necessary U.S. export license. ${ }^{162}$ On March 23, 1989, TMB made a timely demand for payment against the Worthen letter, but then sent instructions eight days later asking Worthen to hold the demand "pending further instructions." 163 April 23 came and went with no more

154. Id. at 728 .

155. The Second Circuit raised, and then avoided, the question of which of two sets of letters of credit actually governed the transaction. The first set, which proclaimed themselves to be irrevocable, said nothing about the number of lots in which Savarin was required to ship the wheat. Id. at 729-30. The second set, which claimed to be "confirming" the first, contained the language requiring multiple shipments. Id. at 730 . The Second Circuit ultimately found that NBP's insistence on a three-lot shipment repudiated its acquiescence to a single-lot shipment in response to Savarin's October 21 cable. Id. at 731 . However, it also suggested that the "confirming" letters of credit may have, themselves, been repudiations of the original irrevocable letters of credit they purported to "confirm." ld. at 729,731 .

156. Id. at 731 .

157. Id.

158. Id.

159. Id.

160. 978 F.2d 440 (8th Cir. 1992).

161. Id. at 440 .

162. Id. at 441.

163. Id. 
word from TMB. On April 3, 1998 BEI notified Worthen that the letter of credit had lapsed, and requested release of its collateral. On May 3, 1989 , Worthen notified TMB that the letter of credit had lapsed and that Worthen believed that TMB's March 23 demand had expired with it. ${ }^{164}$ In November 1989, BEI brought suit against Worthen and TMB to have the letter of credit declared expired and to regain the collateral it had given to Worthen. Worthen, in turn, urged TMB to acknowledge that its rights under the standby letter of credit had expired. Instead, TMB wrote Worthen on February 28, 1990 asking Worthen to extend the standby letter of credit until September 30, 1990. Worthen did not respond to this request, ${ }^{165}$ nor did TMB renew its prior demand or make any other attempt to draw against the letter of credit.

On appeal of the trial court judgment declaring, inter alia, TMB's rights under the standby letter of credit to have expired, ${ }^{166}$ TMB argued that Worthen had anticipatorily repudiated its obligations under the standby letter of credit when it wrote TMB in May 1989 and January 1990 declaring the letter of credit and TMB's March 23 demand expired. ${ }^{167}$ The Eighth Circuit disagreed:

Prior to expiration, TMB by written notice invoked the extension clause and extended the credit to April 23, 1989. When TMB failed to give notice of a further extension prior to April 23, 1989, the letter of credit expired. After expiration, TMB had no unilateral right to revive Worthen's time-specific letter of credit commitment. Even if the parties to the underlying contract intended that Worthen's letter of credit should remain open for the life of TMB's counterguarantee to RTA, the plain language of the letter of credit document is controlling.

Because the letter of credit expired on April 23, 1989, the contentions TMB raises on appeal are without merit. TMB claims that Worthen repudiated the letter of credit in communications that came after April 23, 1989. Obviously, there can be no anticipatory repudiation of a contract that has already expired .... ${ }^{168}$

\section{B. Readiness, Willingness, and Ability to Perform}

To the extent that a beneficiary must prove that she was ready, willing, and able to perform or to tender performance, but for the issuer's repudiation, how may she prove the requisite readiness, willingness, and ability?

164. Id.

165. Id.

166. The district court held that TMB's February 28 letter unilaterally extended the expiration date of the standby letter of credit until September 30, 1990. Id. at 442 . However, because TMB did nothing else before September 30,1990 , the district court held that the letter then expired. Id. The court of appeals disagreed that TMB's letter had the effect the trial court attributed to it, holding, instead, that it had expired on April 23, 1989-the extended expiration date to which Worthen had previously agreed. Id. at 443 . Either way, the standby letter had expired without a timely conforming demand by TMB.

167. Id. at 442 .

168. Id. at 443 . 
In Décor by Nikkei International, Inc. v. Federal Republic of Nigeria, ${ }^{169}$ the plaintiffs established they had the necessary arrangements in place to procure and deliver the concrete that was the subject of the underlying contract on or before the date on which delivery was due. ${ }^{170}$ In Ross Bicycles, Inc. v. Citibank, N.A., ${ }^{171}$ the plaintiff established that, but for the issuer's repudiation, "it would have been in a position to ship goods ... and present drafts for the amount of the balance of the letter of credit." 172

By contrast, in Clement v. FDIC, ${ }^{173}$ the beneficiary (Clement) was unable to establish that it could make a conforming draft against the standby letter of credit because, at the time the issuer's successor-in-interest (FDIC) repudiated, there was, as yet, no breach of the underlying obligation entitling Clement to draw against the standby letter of credit. ${ }^{174}$

Likewise, in De Smeth v. Bank of New York, ${ }^{175}$ De Smeth's predecessor-in-interest (Dikarpa) contracted to sell leather garments to Samsung for $\$ 890,448$. Samsung opened an irrevocable letter of credit with the Bank of New York to pay for the garments. The letter of credit established shipping deadlines of January 20 and February 20, 1990 for different styles of garments. By its terms, the letter of credit expired on March $11,1990 .{ }^{176}$ Dikarpa failed to make any conforming shipments by the agreed deadlines, and submitted two drafts after the letter of credit expired on March 11. ${ }^{177}$ The bank refused to honor a total of six drafts, citing Dikarpa's late shipment as the reason for rejecting the first four drafts and Dikarpa's failure to submit drafts before the letter of credit expired as the reason for rejecting the final two drafts. ${ }^{178}$

While agreeing with De Smeth that the transaction was subject to the anticipatory repudiation provisions of Article 5, despite the letter of credit being expressly subject to the UCP, ${ }^{179}$ the court found that De Smeth had no claim for anticipatory repudiation because the six drafts that Dikarpa presented to the bank "were discrepant and any additional drafts that would have been presented would have been similarly discrep-

169. 497 F. Supp. 893 (S.D.N.Y. 1980), aff'd, 647 F.2d 300 (2d Cir. 1981).

170. Id. at 907-09.

171. 613 N.Y.S.2d 538 (N.Y. Sup. Ct. 1994).

172. Id. at 539; see also Ernesto Foglino \& Co. v. Webster, 216 N.Y.S. 225, 238 (N.Y. App. Div. 1926) (“[T]he record establishes that respondent, on April 16, 1920, had a contract in writing with a responsible corporation for the coal required to fulfill its contract with the Ministry; the coal and ships were available, and the cargoes would have been loaded at Hampton Roads before May 16th. Thus respondent was ready, willing, and able to perform its contract by May 16th, well within the limit of 30 days after April 30th.").

173. 2 UCC Rep. Serv. 2d 1017 (W.D. Okla. 1986).

174. Id. at 1023-24.

175. 879 F. Supp. 13 (S.D.N.Y. 1995).

176. Id. at 14 .

177. Id.

178. Id.

179. Id. at 15 n.1. 
ant since the letter of credit had expired." ${ }^{80}$ Citing Ross Bicycles ${ }^{181}$ for the former's discussion of the independence principle, ${ }^{182}$ the De Smeth court went on to say that Dikarpa's readiness, willingness, and ability to perform the underlying obligation was insufficient grounds to find that it was ready, willing, and able to perform the letter of credit:

Plaintiff's argument that it need only show its ability to fulfill its obligations on the underlying contract is rejected. The only contract governing the relationship between the parties to this action is the letter of credit, and it would be incorrect to look to the underlying contract, entered into by different parties, in analyzing plaintiff's anticipatory repudiation claim. ${ }^{183}$

The final part of the court's statement risks overbreadth. In many letter of credit anticipatory repudiation cases-including Ross Bicycles, the very case the court cites in support of its proposition-a beneficiary's claim (or an issuer's defense) may well rest on the performance of one or more parties to the underlying contract or on their readiness, willingness, and ability to perform the underlying contract. ${ }^{184}$ However, where, as in De Smeth, the issues are non-conforming documents and expiration (rather than cancellation or modification) of the letter of credit, performance of, or readiness, willingness, and ability to perform, the underlying contract is (or may be) a necessary, but not sufficient, condition for a beneficiary seeking to recover under the theory of anticipatory repudiation.

\section{The Beneficiary's Recourse}

Assuming that the issuer repudiated and that the beneficiary was (if it needed to be) ready, willing, and able to perform any condition precedent to its right to payment under the repudiated letter of credit, what recourse is available to a beneficiary so wronged?

The version of Article 5 currently in effect in forty-nine states and the District of Columbia, ${ }^{185}$ provides that a beneficiary whose issuer, before presentation, repudiates its obligation to pay the beneficiary under the letter of credit before presentation may "recover from the issuer the amount that is the subject of the . . repudiation," plus incidental damages, interest "from the date of wrongful dishonor or other appropriate date," and reasonable attorneys' fees and other expenses of litigation incurred by the beneficiary in enforcing its rights against the repudiating

180. Id. at 15 .

181. Ross Bicycles, Inc. v. Citibank, N.A., 613 N.Y.S.2d 538 (N.Y. Sup. Ct. 1994); see supra notes $99,171-72$ and accompanying text.

182. See supra note 27.

183. De Smeth, 879 F. Supp. at 15.

184. See, e.g., Décor by Nikkei Int'l, Inc. v. Fed. Republic of Nigeria, 497 F. Supp. 893, 907-09 (S.D.N.Y. 1980) (discussed supra text accompanying notes 169-70), aff'd, 647 F.2d 300 (2d Cir. 1981); Clement v. FDIC, 2 UCC Rep. Serv. 2d 1017, 1023-25 (W.D. Okla. 1986) (discussed supra text accompanying notes 173-74); Ross Bicycles, 613 N.Y.S.2d at 539 (discussed supra text accompanying notes 171-72).

185. See supra note 36. 
issuer. ${ }^{186}$ If, before presentation, the issuer repudiates an obligation other than to pay money, the beneficiary may obtain specific performance, or at the beneficiary's option, may recover the value of the issuer's performance; and, in either case, the beneficiary may recover incidental damages. ${ }^{187}$ The beneficiary is not entitled to recover consequential, exemplary, or punitive damages. ${ }^{188}$ Nor is the beneficiary obligated to mitigate its damages caused by the issuer's repudiation. ${ }^{189}$ However, if the beneficiary undertakes to avoid some or all of its damages, any damages

186. See U.C.C. \$ 5-111(a), (d), (e) (1995); see, e.g., Amwest Sur. Ins. Co. v. Concord Bank, 248 F. Supp. 2d 867, 883-84 (E.D. Mo. 2003) (awarding the beneficiary the face value of the letter of credit and prejudgment interest from the last date after presentation on which the issuer could have timely honored the beneficiary's draft, and instructing the beneficiary to submit detailed affidavits to enable the court to ascertain and award its reasonable attorneys' fees and litigation expenses). See generally 1 Dolan, supra note 11, II 9.02[5]; 6B HAWKLAND \& MILleR, supra note 37, [Rev.] § 5-111:1; 7A LAWRENCE, supra note 89 , [Rev.] $\$ \$ 5-111: 6$ to :11.

Former section 5-115(2) did not permit a beneficiary to recover attorneys' fees and litigation expenses unless its letter of credit with the issuer so provided. See 1 Dolan, supra note 11, I 9.02[5][c] \& n.147; 3 WhITE \& Summers, supra note 112, at 204 \& n.6. It was not enough for the underlying contract between the beneficiary and the applicant to provide for attorneys' fees and expenses. See 1 DoLan, supra note 11, II 9.02[5][c] \& n.148.

Because the UCP500, the ISP98, and the U.N. Convention are all silent with respect to remedies for anticipatory repudiation (and, for that matter, remedies for wrongful dishonor), Article 5 governs the beneficiary's remedies for anticipatory repudiation notwithstanding the parties' incorporation of one or more of the foregoing into their letter of credit. See U.C.C. \$ 5-116(c); UCP500, supra note 1, art. 1; ISP98, supra note 10, R. 1.01(b); U.N. Convention, supra note 34, arts. 1(2), 21; cf. Bank of Joliet v. Firstar Bank Milwaukee, N.A., No. 96 C 1145, 1997 U.S. Dist. LEXIS 15384, at *34-36 (N.D. Ill. Sept. 30,1997 ) (finding that, while the parties expressly incorporated the UCP500 into their letter of credit, Article 5 would dictate the remedy for a beneficiary whose issuer wrongfully dishonored, because the UCP500 neither provides nor denies a remedy for wrongful dishonor).

187. U.C.C. § 5-111(a). See generally 7A LAWRENCE, supra note 89, [Rev.] § 5-111:14.

188. See U.C.C. \& 5-111(a) ("[T]he claimant may also recover incidental but not consequential damages."); see id. \$ 5-111 cmt. 4 ("Consequential damages ... are excluded in the belief that these damages can best be avoided by the beneficiary or the applicant and out of the fear that imposing consequential damages on issuers would raise the cost of the letter of credit to a level that might render it uneconomic. A fortiori punitive and exemplary damages are excluded ...."); see, e.g., Amwest Sur., 248 F. Supp. 2d at 883 (quoting U.C.C. \& 5-111(a) \& cmt. 4 en route to denying the beneficiary's claim for punitive damages); ITM Enters., Inc. v. Bank of N.Y., 754 N.Y.S.2d 663, 665 (N.Y. App. Div. 2003) (affirming the trial court's summary judgment order dismissing a beneficiary's claim for punitive damages because "[a] claimant under a letter of credit may recover the amount that is the [subject] of the dishonor or repudiation, as well as incidental damages, but not consequential or punitive damages"); see also Décor by Nikkei, 497 F. Supp. at 911-12 (applying U.C.C. § 1-106(1) to justify refusing to award punitive damages, despite the beneficiaries' claim that the issuer "maliciously" repudiated the letters of credit in their favor). See generally 1 DoLAN, supra note 11, T 9.02[5][d].

A beneficiary may recover consequential damages, notwithstanding the general prohibition in section 5-111, if the letter of credit specifically provides for them. See generally $6 \mathrm{~B}$ HaWKLAND \& MilLER, supra note 37, [Rev.] \& 5-111:1.

189. U.C.C. § 5-111(a); see, e.g., Amwest Sur., 248 F. Supp. 2d at 883 ("A beneficiary ... has no duty ... to mitigate its damages; its damages are for the breach of its credit contractual relationship with the issuing bank and the appropriate measure of such damages is the face value of the LOC."); see also, e.g., Optopics Labs. Corp. v. Savannah Bank of Nig., Ltd., 816 F. Supp. 898, 909 (S.D.N.Y. 1993); San Diego Gas \& Elec. Co. v. Bank Leumi, 50 Cal. Rptr. 2d 20, 27 (Cal. Ct. App. 1996); Pioneer Bank \& Trust Co. v. Seiko Sporting Goods, U.S.A. Co., 540 N.E.2d 808, 813 (IIl. App. Ct.), appeal denied, 548 N.E.2d 1078 (Ill. 
it avoids will reduce the beneficiary's recovery from the repudiating issuer. ${ }^{190}$

Former section 5-115-still the law of Wisconsin ${ }^{191}$ —afforded a nonrepudiating beneficiary who learned of the issuer's repudiation "in time to reasonably avoid procurement of the required documents," the "rights of a seller after anticipatory repudiation by the buyer under Section 2-610."192 Applying section 2-610 would lead a beneficiary who chose to respond to the issuer's repudiation by doing something other than suspending its own performance and urging retraction to section 2703.193

Section 2-703, in turn, would entitle the nonrepudiating beneficiary to: (1) sue the repudiating issuer for the face value of the repudiated draft or letter-Article 5's surrogate for the contract price-plus incidental damages and interest; ${ }^{194}(2)$ resell the goods or services that were the subject

1989) (all finding no duty to mitigate damages under former Article 5). See generally 1 DOLAN, supra note 11, II 9.02[5][b]; 7A LAWRENCE, supra note 89, [Rev.] \& 5-111:12.

190. U.C.C. \$ 5-111(a). See generally 1 DoLAN, supra note 11, Il 9.02[5][a]; 7A LAWRENCE, supra note 89, [Rev.] § 5-111:12.

191. See supra note 36.

192. See U.C.C. \$ 5-115(2) (1962). See generally 6B HawkLANd \& Holland, supra note 37, § 5-115:1; 7A LAWRENCE, supra note 89, \& 5-115:11.

Treating the beneficiary as a seller whose buyer has repudiated poses a challenge when dealing with a standby letter of credit for which the underlying obligation is a promissory note or similar arrangement obligating, rather than a contract for the sale of goods or services.

Section 5-115 unfortunately was drafted with only commercial letters of credit in mind; therefore a problem arises in applying $\$ 5-115$ to standby letters of credit: there are no goods for the beneficiary to resell when the issuer dishonors a standby letter of credit. The question thus arises as to whether the [issuer] should be permitted to prove that the beneficiary's actual damages are less than the amount of the draw or whether the bank is liable for the full amount of the draw. Because one of the primary purposes of a standby letter of credit is to put the proceeds in the hands of the beneficiary pending resolution of the [underlying] dispute in court, courts should not attempt to resolve the underlying dispute in the [beneficiary's] case [against the issuer]. Hence, the damages for standby letters of credit should be the full amount of the draw.

3 Crandall ET AL., supra note 90, $\$ 21.8 .3$ (footnotes omitted). While the foregoing overgeneralizes by failing to recognize that the contracts underlying some standby letters of credit are for the purchase and sale of goods or services, see supra note 12, it does point out one of the reasons the drafters of Revised Article 5 may have chosen to remove the reference to section 2-610 when they crafted section 5-111(a) to replace former section 5$115(2)$.

193. See U.C.C. $\$ 2-610$ (b) (1989).

194. See id. \$§ 2-709, 2-710; see, e.g., Atari, Inc. v. Harris Trust \& Sav. Bank, 599 F. Supp. 592, 600-01 (N.D. Ill. 1984) (awarding the beneficiary of a $\$ 1.5$ million letter of credit $\$ 395,391.68$ - the amount of the draw the beneficiary attempted to make following the issuer's repudiation), aff'd in part and rev'd in part, 785 F.2d 312 (7th Cir. 1986); Ross Bicycles, Inc. v. Citibank, N.A., 613 N.Y.S.2d 538, $541-43$ (N.Y. Sup. Ct. 1994) (awarding the beneficiary the as-yet unpaid balance of the face value of the letter of credit, plus interest from the date the issuer anticipatorily repudiated); see also, e.g., Clement v. FDIC, 2 U.C.C. Rep. Serv. 2d 1017, 1031 (W.D. Okla. 1986) (having found that the beneficiaries were not entitled to recover for anticipatory repudiation because they failed to establish their readiness, willingness, and ability to perform but for the issuer's repudiation, see supra text accompanying notes 173-74, nonetheless awarding the beneficiaries judgment for the face value of wrongfully dishonored letters of credit, plus interest, less any amount 
of the letter of credit between the beneficiary and the issuer and sue the issuer for the difference between the contract price promised by the applicant-in whose stead the issuer promised to pay, and then repudiated that promise - and the price at which the beneficiary resold, plus incidental damages and interest, less expenses saved as a consequence of the issuer's repudiation; ${ }^{195}$ (3) sue the repudiating issuer for the difference between the payment the beneficiary reasonably expected under the letter of credit for its goods or other performance and their market price at the time and place for tender, plus incidental damages and interest, less expenses saved as a consequence of the issuer's repudiation; ${ }^{196}$ or (4) if awarding the nonrepudiating beneficiary its expectancy would be "inadequate to put the [beneficiary] in as good a position as performance would have done," sue the repudiating issuer for the beneficiary's lost profit, plus incidental damages and interest. ${ }^{197}$

Section 2-703 would also entitle the nonrepudiating beneficiary to cancel the letter of credit, ${ }^{198}$ but it is unclear how that would benefit the beneficiary, because the independence principle would not allow the beneficiary to cancel its contract with the applicant based on the issuer's repudiation, unless the contract between the beneficiary and the applicant so provided. If the beneficiary had already procured the required documents, former section 5-115 entitled the beneficiary to recover the "face amount" of the repudiated draft or letter, together with incidental damages and interest-the same remedy afforded to beneficiaries whose presentations had been wrongfully dishonored. ${ }^{199}$

There is no indication in either the prefatory note or the official comments to Revised Article 5 that its drafters intended, in any way, to re-

the beneficiaries have received from third parties as a consequence of being released from their obligation to the applicant).

195. See U.C.C. $\$ \$ 2-706,2-710$; see, e.g., Savarin Corp. v. Nat'l Bank of Pak., 447 F.2d $727,731-32$ (2d Cir. 1971) (affirming the jury's award of $\$ 60,500$ as compensation for the difference between the contract price between the beneficiary and the applicant and the price at which the applicant was forced to liquidate their wheat commitments following the issuer's repudiation of the commercial letter of credit, plus incidental damages).

196. See U.C.C. $\$ \S 2-708(1), 2-710$.

197. U.C.C. $\$ \$ 2-708(2), 2-710$; see, e.g., Décor by Nikkei Int'l, Inc. v. Fed. Republic of Nigeria, 497 F. Supp. 893, 908-09, 911-12 (S.D.N.Y. 1980) (awarding two beneficiaries whose issuer anticipatorily repudiated letters of credit in their favor the difference between the price at which they purchased cement for purposes of resale to the applicant and the contract price the issuer agreed to pay on behalf of the applicant, plus incidental damages and interest), aff'd, 647 F.2d 300 (2d Cir. 1981); see also Ernesto Foglino \& Co. v. Webster, 216 N.Y.S. 225, 239 (N.Y. App. Div. 1926) (holding under pre-Code common law that the beneficiary was entitled to recover the difference between its contract price to sell coal subject to payment by the letter of credit issuer and the price at which the beneficiary procured the coal for export to the applicant).

198. See U.C.C. $\$ 2-703(\mathrm{f})$.

199. See U.C.C. § 5-115(1) \& (2) (1962); see, e.g., Pringle-Associated Mortgage Corp. v. S. Nat'l Bank, 571 F.2d 871, 875 (5th Cir. 1978) (reversing judgment against beneficiary for failing to comply with conditions that were not part of the letter of credit, and remanding with instructions to award the beneficiary the amount of the dishonored draft- $\$ 125,000-$ plus interest and any incidental damages the beneficiary could prove to the district court's satisfaction). See generally 6B HAWkLAND \& Holland, supra note 37, \& 5-115:1; 7A LAWRENCE, supra note 89, § 5-115:12; 3 WHITE \& SUMMERS, supra note 102, at 208. 
duce the remedial options available to a beneficiary whose issuer anticipatorily repudiates. Indeed, the prefatory note describes section 5111 as "expand[ing]" the remedies available to beneficiaries. ${ }^{200}$ And, yet, section 5-111 only explicitly affords a beneficiary a single measure of compensatory damages: "the amount that is the subject of the ... repudiation," 201 which is comparable to former section 5-115(2)'s granting a beneficiary the functional equivalent of an action for price. ${ }^{202}$ Section 5111 makes no explicit provision for a beneficiary recovering the difference between the contract price of its goods or services and their resale price, ${ }^{203}$ the difference between the contract price of its goods or services and their market value at the time and place of tender, ${ }^{204}$ or the profits lost by the beneficiary as a result of the issuer's repudiation. ${ }^{205}$ Nor have the leading commentators opined on the effect of these omissions. ${ }^{206}$

The text of, and comments to, Revised Article 5 are also silent about whether a beneficiary may demand adequate assurances from an issuer who has given the beneficiary reasonable grounds for insecurity (or, for that matter, whether a repudiating issuer may retract its repudiation before the nonrepudiating beneficiary materially changes position or otherwise treats the repudiation as final).

Former section 5-115(2) was arguably silent on these issues, too, providing only that the nonrepudiating beneficiary who learned of the issuer's repudiation prior to procuring the documents required to make a conforming presentation had "the rights of a seller after anticipatory repudiation by the buyer under Section 2-610."207 A seller's right to demand adequate assurances of performance arises under section 2-609, not section 2-610.208 Thus, a strict reading of the text of former section 5115 (2) could lead one to the conclusion that, while a nonrepudiating ben-

200. Prefatory Note to U.C.C. Revised Article 5 (1995) ("The damages provided are expanded and clarified. They include attorneys fees and expenses of litigation and payment of the full amount of the wrongfully dishonored or repudiated demand, with interest, without an obligation of the beneficiary to mitigate damages."); see also 3 WHITE \& SUMMERS, supra note 102, at 210-11 (discussing the extent to which Revised Article 5 "restates, clarifies and adds to" the remedies provided by former section 5-115 and the case law that developed around it); Dellas W. Lee, Letters of Credit: What Does Revised Article 5 Have to Offer to Issuers, Applicants, and Beneficiaries?, 101 CoM. L.J. 234, 261 (1996) ("Section 5-111 contains several remedial benefits to the beneficiary that are either new, or were not clearly spelled out under prior law. . . . The composition of remedies in this section is designed to achieve two important goals: (1) full compensation to the beneficiary in the event of breach, and (2) to provide a strong incentive for the issuer to honor the letter of credit when properly presented.").

201. U.C.C. \$ 5-111(a) (1995).

202. See supra text accompanying note 194.

203. See supra text accompanying note 195.

204. See supra text accompanying note 196.

205. See supra text accompanying note 197.

206. See 3 CRANDALl ET AL., supra note 90, § 21.8.3; 1 Dolan, supra note 11, II 9.02[5]; 6B HawkLAND \& Miller, supra note 37, [Rev.] \$ 5-111:1; 7A LAWRENCE, supra note 89, [Rev.] $\$$ 5-111:5 to :14; 2 QuinN, supra note 94, [Rev.] $\$ 5-111 ; 3$ WhITE \& Summers, supra note $102,210-11$.

207. U.C.C. § 5-115(2) (1962); see supra text accompanying notes 192-98.

208. See U.C.C. $\$ 2-609$ (1989); supra note 70 and accompanying text. 
eficiary was entitled, following a repudiation by the issuer that would substantially impair the value of the letter of credit to the beneficiary, to wait a commercially reasonable time for the issuer to perform, urge the issuer to retract its repudiation, sue the issuer for breach, and, in any event, suspend his own performance-all rights granted under section 2$610^{209}$ - the nonrepudiating beneficiary was not entitled to demand that the issuer provide adequate assurances of performance before the beneficiary resorted to section 2-610. Surely such a strict reading, however, would have missed the drafters' intent. The official comments to section 2-610, read along with the text of and official comments to sections 2-609 and 2-611, clearly contemplate section 2-610 to be part of a tri-partite whole made up of sections 2-609, 2-610, and 2-611.210 Isolating section 2610 from section 2-609, to the end of denying a nonrepudiating beneficiary the right to seek assurances from a repudiating issuer in the same manner and under the same constraints as Article 2 allows a nonrepudiating seller the right to seek assurances from a repudiating buyer, gives the nonrepudiating beneficiary fewer rights than Article 2 gives the nonrepudiating seller. Similarly, isolating section 2-610 from section 2611 -an even more difficult task given the explicit reference in the text of

209. See U.C.C. \$ 2-610; supra notes $69,71-77$ and accompanying text.

210. See U.C.C. $\$ 2-609$ (1) (providing that "[a] contract for sale imposes an obligation on each party that the other's expectation of receiving due performance will not be impaired"-an obligation that would clearly be breached by anticipatory repudiation under section 2-610); id. § 2-609 cmt. 2 ("[T] his section provides the means by which the aggrieved party may treat the contract as broken if his reasonable grounds for insecurity are not cleared up within a reasonable time. This is the principle underlying the law of anticipatory breach, whether by way of defective part performance or by repudiation." (emphasis added)); id. $\$ 2-609 \mathrm{cmt}$. 5 ("A failure to provide adequate assurance of performance and thereby to reestablish the security of expectation, results in a breach only 'by repudiation' under subsection (4). Therefore, the possibility is continued of retraction of the repudiation under the section dealing with that problem, unless the aggrieved party has acted on the breach in some manner." (emphasis added)); id. \$ 2-610(b) (allowing the nonrepudiating party to "[r]esort to any remedy for breach" afforded by Article 2 even though he has urged the repudiating party to retract); id. $\S 2-610 \mathrm{cmt}$. 1 (referencing section 2-609 as "tak[ing] care of" the "problem of insecurity" before setting forth the test for anticipatory repudiation); id. \$2-610 cmt. 2 ("[A] repudiation automatically results under the preceding section on insecurity when a party fails to provide adequate assurance of due future performance within thirty days after a justifiable demand therefor has been made." (emphasis added)); id. $\$ 2-611(1)$ (allowing the repudiating party, until its next performance is due, to retract its repudiation "unless the aggrieved party has since the repudiation cancelled or materially changed his position"-both rights afforded the nonrepudiating party under section 2-610(b) - or "otherwise indicated that he considers the repudiation final"); id. $\S 2$ 611(2) ("Retraction may be by any method which clearly indicates to the aggrieved party that the repudiating party intends to perform, but must include any assurance justifiably demanded under the provisions of this Article (Section 2-609)."); id. § 2-611 cmt. 1 ("The repudiating party's right to reinstate the contract is entirely dependent upon the action taken by the aggrieved party. If the latter has cancelled the contract or materially changed his position at any time after the repudiation, there can be no retraction under this section."); id. $\S 2-611 \mathrm{cmt} .2$ ("[A]n effective retraction must be accompanied by any assurances demanded under the section dealing with right to adequate assurance. A repudiation is of course sufficient to give reasonable ground for insecurity and to warrant a request for assurance as an essential condition of the retraction. However, after a timely and unambiguous expression of retraction, a reasonable time for the assurance to be worked out should be allowed by the aggrieved party before cancellation." (emphases added)). 
section 2-610(b) to "urg[ing] retraction" 211 - to the end of denying a repudiating issuer the right to retract its repudiation before the nonrepudiating beneficiary materially changes its position or otherwise indicates that it considers the issuer's repudiation to be final in the same manner and under the same constraints as Article 2 allows a repudiating buyer the right to retract its repudiation before the nonrepudiating seller materially changes its position or otherwise indicates that it considers the buyer's repudiation to be final, gives the repudiating issuer fewer rights than Article 2 gives the repudiating buyer. Such outcomes seem inconsistent with distinguishing anticipatory repudiation from wrongful dishonor as the drafters of former Article 5 chose to do by setting former section 5115(2) apart from former section 5-115(1) and as the drafters of Revised Article 5 chose to do by recognizing a beneficiary's right to remedy when "an issuer . . . repudiates its obligation to pay money under a letter of credit before presentation" as a basis for relief separate from a beneficiary's right to remedy when "an issuer wrongfully dishonors." 212

Reported case law on whether a beneficiary has the right to demand adequate assurances from an issuer-and the more important corollary right to treat an issuer's failure to provide adequate assurances following a justified demand-is virtually nonexistent. What little exists suggests that, at least under former Article 5, a beneficiary had the right to demand assurances. ${ }^{213}$ Likewise, there is limited authority supporting the beneficiary's right to urge the repudiating issuer to retract-and the issuer's much more important corollary right to retract prior to any act by the beneficiary cutting off the issuer's right to retract. ${ }^{214}$ The leading commentators are generally silent on the issues of adequate assurances and retraction under both former section 5-115(2) and revised section 5$111 . .^{215}$

211. U.C.C. $\S 2-610(b)$.

212. U.C.C. § 5-111(a), (b) (1995); see also id. § 5-111 cmt. 1.

213. Cf. Monter Joint Stock Co. v. Udruzena Beogradska Banka, 684 N.Y.S.2d 214, 215 (N.Y. App. Div. 1999) ("Plaintiff"s present claim of anticipatory breach based on the banks' failure to offer to honor the letter of credit once sanctions are lifted in the future is improperly raised for the first time on appeal, and, in any event, is without merit absent allegations or proof that plaintiff ever made the requisite demand for assurances of future performance." (citing Norcon Power Partners v. Niagara Mohawk Power Corp., 705 N.E.2d 656 (N.Y. 1998))).

214. See Atari, Inc. v. Harris Trust \& Sav. Bank, 599 F. Supp. 592, 601 (N.D. Ill. 1984) (holding that the beneficiary's presentation following the issuer's repudiation was "no more than a further urging that [the issuer] retract its repudiation and perform under the credit" and that, had the issuer at that point properly dishonored the beneficiary's draft as nonconforming, the dishonor "would amount to . . . a retraction of its prior repudiation" because "[s]hould the issuer properly dishonor an attempted draw made subsequent to its repudiation, it has performed under the credit and retracted its repudiation"), aff'd in part and rev'd in part, 785 F.2d 312 (7th Cir. 1986).

215. See 3 CRANDAll ET AL., supra note 90, \& 21.8.3; 1 Dolan, supra note 11, II 9.02[5]; 6B HaWKLAND \& Holland, supra note 37, § 5-115:1; 6B Hawkland \& Miller, supra note 37, [Rev.] \& 5-111:1; 7A LAWRENCE, supra note $89, \$ 5-115: 13$, :15 to :21; id. [Rev.] \& 5$111: 5$ to :14; 2 QuIN, supra note 97 , [Rev.] § 5-111; 3 WhITE \& SumMERS, supra note 102 , at $208,210-11$.

Professor Quinn offers the following comment without any further illumination: 


\section{CONCLUSION}

The letter of credit is a useful tool that can facilitate a commercial transaction by providing either a payment or financing mechanism or by guaranteeing satisfactory performance....

In a sale of goods context, the seller/beneficiary can use the letter of credit as collateral to finance production. Once the goods are shipped, the seller is assured prompt payment upon presentation of complying documents. Consequently, the seller avoids delays incurred in billing and collection of the purchase price. The buyer/ customer, on the other hand, avoids prepaying the entire amount of the purchase prior to its shipment without any assurance of satisfactory performance. Because the letter of credit mechanism permits the buyer to specify that certain documents accompany the draft for payment, the buyer can be reasonably assured that complying documents will signify adequate performance.

In a standby letter of credit, the beneficiary knows that a creditworthy party will pay upon presentment of documents that substantiate the claim of default or nonperformance. The customer or "guaranteed" party benefits by not having to escrow the funds or otherwise restrict the use of funds. ${ }^{216}$

These advantages do not come without corresponding risks. Introducing a third party - the letter of credit issuer - to the transaction may allow an applicant to enjoy the benefits of some transaction that it would otherwise have to forego because of the erstwhile beneficiary's unwillingness to extend credit to the applicant or to accept payment in a form, at a time, or at a place that is less convenient to the beneficiary than promised by the letter of credit. On the other hand, a third party who has no vested interest in the underlying transaction may be more inclined than an interested party would be to repudiate its obligation.

An issuer's repudiation, at the very least, deprives the beneficiary of the full benefit of her bargain, in that it forces her to rely on the creditworthiness of an applicant who she deemed insufficiently creditworthy in the first place, thus her decision to require the letter of credit. And, if the beneficiary's initial estimation of the applicant bears out, the beneficiary will suffer a real loss. ${ }^{217}$

\footnotetext{
Neither 5-115, nor its Official Comment suggests . . how the anticipatory repudiation rules of the sales act that involve[ ] a two-party relationship between seller and buyer are intended to apply to the three-party relationship between seller-issuer-buyer, save to say that this "states the rights of the beneficiary upon repudiation of the credit, both against the issuer and with respect to any goods."
}

2 QuinN, supra note 94, $\$$ 5-115(A)(3) (quoting U.C.C. $\$ 5-115 \mathrm{cmt} .2$ ).

216. Leon, supra note 2 , at 463 .

217. If the issuer's repudiation comes before the beneficiary has fully performed, then the applicant, too, may be injured by the issuer's repudiation, if the beneficiary views the issuer's repudiation as a repudiation by, or at least reasonable grounds to demand adequate assurances of performance from, the applicant. Revised Article 5 appears to afford 
For these reasons, Article 5 affords relief to a beneficiary whose issuer clearly and unconditionally manifests its intent not to honor, or its inability to honor, her conforming presentation when and as promised. However, given the widespread adoption of Revised Article 5 and its less explicit anticipatory repudiation provision, it is unclear whether such a beneficiary any longer has the choice of remedies she was granted by former Article 5.218 Moreover, her right to justifiably demand adequate assurances of performance and her issuer's right to retract its repudiation at any time prior to her detrimentally relying on it, both of which are express in Article 2 and were impliedly incorporated by former section 5115(2), seem even more tenuous than they were under former Article 5. ${ }^{219}$ Taken at face value, Revised Article 5 could be read to afford a beneficiary whose issuer repudiates prior to the time its honor is due little more (though no less) than a beneficiary whose issuer wrongfully dishonors at or after the time its honor is due-no more than the right not to have to prepare for and make a conforming presentation, only to have it rejected by the issuer. If the drafters of Revised Article 5 intended otherwise, or the courts who must apply Revised Article 5 think otherwise, the time is ripe for more definitive guidance.

the applicant a remedy against the issuer in such a case. See U.C.C. \$ 5-111(b). However, a discussion of the applicant-issuer relationship is beyond the scope of this article.

218. See supra text accompanying notes 186-206.

219. See supra text accompanying notes 207-15. 
